\title{
3. SITE 505: SEDIMENTS AND OCEAN CRUST IN AN AREA OF LOW HEAT FLOW SOUTH OF THE COSTA RICA RIFT1
}

\author{
Shipboard Scientific Party²
}

\section{HOLE 505}

Date occupied: 29 September 1979, $1200 \mathrm{Z}$

Date departed: 1 October 1979, $2400 \mathrm{Z}$

Time on hole: 60 hours

Position: $01^{\circ} 54.8^{\prime} \mathrm{N} ; 83^{\circ} 47.4^{\prime} \mathrm{W}$

Water depth (sea level; corrected m, echo-sounding): 3537

Water depth (rig floor; corrected m, echo-sounding): 3547

Bottom felt (m, drill pipe): 3548.5

Penetration (m): 242.0

Number of cores: 26

Total length of cored section $(m): 223$

Total core recovered $(\mathrm{m}): 187.05$

Core recovery $(\%): 72$

Oldest sediment cored:

Depth sub-bottom (m): 232

Nature: Gray green siliceous nannofossil ooze

Age: $3.9 \mathrm{~m} . \mathrm{y}$.

Measured velocity $(\mathrm{km} / \mathrm{s}): 1.51$

Basement:

Depth sub-bottom (m): 232

Nature: Highly fractured basalts

Velocity range $(\mathrm{km} / \mathrm{s}): 5.80-5.95$

Principal results: See discussion following site data for Hole 505B.

\section{HOLE 505A}

Date occupied: 2 October 1979, $0255 \mathrm{Z}$

Date departed: 2 October 1979, $2400 \mathrm{Z}$

Time on hole: 21 hours

Position: $01^{\circ} 55.1^{\prime} \mathrm{N} ; 83^{\circ} 47.4^{\prime} \mathrm{W}$

Water depth (sea level; corrected m, echo-sounding): 3525

\footnotetext{
${ }^{1}$ Cann, J. R., Langseth, M. G., Honnorez, J., Von Herzen, R. P., White, S. M., et al. Init. Repts. DSDP, 69: Washington (U.S. Govt. Printing Office).

2 J. R. Cann (Co-Chief Scientist), Department of Geology, University of Newcastle upon Tyne, Newcastle upon Tyne, United Kingdom; Marcus Langseth (Co-Chief Scientist), Lamont-Doherty Geological Observatory, Columbia University, Palisades, New York; A. C. Adamson, Department of Geology, University of Newcastle upon Tyne, Newcastle upon Tyne, United Kingdom; Roger N. Anderson, Lamont-Doherty Geological Observatory, Columbia University, Palisades, New York; Helmut Beiersdorf, Bundesanstalt für Geowissenschaften und Rohstoffe, Hannover, Federal Republic of Germany; Toshio Furuta, Ocean Research Institute, University of Tokyo, Nakano, Tokyo, Japan; Michael J. Mottl, Department of Chemistry, Woods Hole Oceanographic Institution, Woods Hole, Massachusetts James H. Natland, Deep Sea Drilling Project, Scripps Institution of Oceanography, La Jolla California; Vladislav L. Nekhoroshkov, Institute of Geophysies, Peromayskaya 91, Sverd-

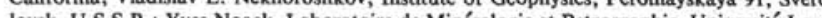
, Fine Pasteur, Strasbourg Cedex, France (present address: Laboratoire de Pétrologie de la Surface, Université de Poitiers, Poitiers Cedex, France); Nickolai N. Pertsev, Institute of Geology of Ore Deposits, Petrology, Mineralogy, and Geochemistry, U.S.S.R. Academy of Sciences, Moscow, U.S.S.R.; Constance Sancetta, Lamont-Doherty Geological Observatory, Columbia University, Palisades, New York; and Roy H. Wilkens, Department of Geological Sciences, University of Washington, Seattle, Washington (present address: Department of Earth and Planetary Sciences, Massachusetts Institute of Technology, Cambridge, Massachusetts).
}

Water depth (rig floor; corrected m, echo-sounding): 3535

Bottom felt (m, drill pipe): 3535

Penetration (m): 208.5

Number of cores: 2

Total length of cored section (m): 12

Total core recovered $(\mathrm{m}): 0.75$

Core recovery $(\%): 6$

Basement:

Depth sub-bottom (m): 196.5

Nature: Fractured basalts

Principal results: See discussion following site data for Hole 505B.

\section{HOLE 505B}

Date occupied: 3 October 1979, 0000Z

Date departed: 7 October 1979, 1200Z

Time on hole: 108 hours

Position: $01^{\circ} 55.2^{\prime} \mathrm{N} ; 83^{\circ} 47.3^{\prime} \mathrm{W}$

Water depth (sea level; corrected m, echo-sounding): 3507

Water depth (rig floor; corrected m, echo-sounding): 3517

Penetration (m): 178.0

Number of cores: 6

Total length of cored section (m): 42

Total core recovered $(\mathrm{m}): 6.85$

Core recovery $(\%): 16.3$

Basement:

Depth sub-bottom (m): 136

Nature: Highly fractured basalts

Velocity range $(\mathrm{km} / \mathrm{s}): 5.85-5.95$

Principal results: Holes 505, 505A, 505B-Site 505 is in an area of the Costa Rica Rift where seafloor heat flow measurements indicate anomalously low conductive heat flow, a condition that implies low basement temperatures. Three holes were drilled at Site 505 in the floor of a broad east-west-trending trough. The water depth was 3535 meters, about 60 meters deeper than at the older Site 504 . The 232-meter sedimentary section at Hole 505 was continuously cored by rotary drilling. It was made up entirely of a grayish green to olive grayish green siliceous nannofossil ooze that represented a complete section from the early Pliocene $(\sim 3.9 \mathrm{Ma})$ to the present. Diatom markers indicated a sedimentation rate of about $60 \mathrm{~m} /$ m.y. Only three distinct ash layers were found, at 3.9, 16.6, and 26.4 meters. The 20 meters of sediment above basement were distinctly chalky and compact, but the remainder of the section showed little evidence of compaction or diagenesis. Temperatures measured at four points between 86 and 210 meters indicated a uniform gradient of $2^{\circ} \mathrm{C}$ per 100 meters and basement temperatures of approximately $9^{\circ} \mathrm{C}$. Interstitial water from squeezed samples and four in situ samples showed evidence for strongly reducing conditions at sub-bottom depths up to 100 meters. Reducing conditions were further evidenced by a very strong smell of hydrogen sulfide in all cores. The pore water chemistry profiles, low 
temperatures, lack of density gradients, and lack of diagenetic effects in the upper 210 meters of sediment were in sharp contrast to the characteristics of Site 504.

Basement rocks were drilled for 9.5 meters in Hole 505, 12 meters in Hole 505A, and 42 meters in Hole 505B. Drilling conditions were difficult, and the percentage of recovery was low. The rocks were fractured, relatively fresh basalts. Alteration rinds frequently bordered cracks. Minerals found in cracks included phillipsite, pyrite, smectite, and calcite. The basalts at Site 505 were little fractionated, with an average value of $\mathrm{Mg} /(\mathrm{Mg}+\mathrm{Fe})$ of 0.64 . The Hole 505 basalts have large phenocrysts of plagioclase, olivine, and clinopyroxene and smaller crystals of chrome-spinel. The basalts in Holes 505A and 505B were nearly identical to these except that they were more sparsely phyric and lacked phenocrysts of clinopyroxene.

Three suites of logs were successfully run in Hole 505B in the lower part of the sedimentary section and the entire basement section. The logs showed considerable density variation at the scale of meters. The variation probably corresponded to interbedded pillow lava flows, zones of rubbly basalt, and sedimentary interlayers. The downhole magnetometer showed the drilled section of basalt to be uniformly reversely magnetized. Measurements made on core samples confirmed this result and indicated a low inclination angle relative to the present field, high intensities of magnetization, and low susceptibilities.

\section{OPERATIONS}

Site 505 (Site Survey Target CR-2) is located in the floor of a broad east-west-trending graben (see Fig. 1) centered at $1^{\circ} 55^{\prime} \mathrm{N}$. The southern wall of the graben is made up of steplike normal faults with vertical displacements of 100 to 200 meters. The site survey observations showed that this feature is characterized by anomalously low heat flow-about $10 \%$ of the theoretically anticipated value. The floor of the graben is about 1.5 meters wide and is at depths from 3510 to $\mathbf{3 5 3 0}$ meters near Site 505. A postdrilling survey made with the Gloria's sidescan sonar shows the trough to be continuous and linear for at least $30 \mathrm{~km}$ (Searle, this volume). Because the trough could be identified easily, the beacon was dropped during the first pass over it (at $1224 \mathrm{hr} ., 29$ Sept. 1979).

Three single-bit holes were drilled in a north-south line at Site 505 .

\section{Hole 505}

Hole 505 was located several hundred meters north of the deepest fault scarp on the south wall of the graben. We began running pipe into Hole 505 during the afternoon of 29 September. The bottom hole assembly (BHA) contained the Lynes packer subassembly and a torque jar, a device for applying sudden shocks to the BHA if it jammed in the basement. We intended to run experiments using the packer as soon as we could drill a sufficiently deep hole in a suitable basement formation. Hole 505 was spudded into seafloor sediments at $0200 \mathrm{hr}$. on 30 September at a water depth of 3537 meters.

Continuous rotary coring was begun at the mudline (Table 1). Coring was interrupted at $86,143,181$, and 210 meters sub-bottom to make observations with the downhole temperature probe and to take in situ pore water samples. All four measurement runs were successful. Two intervals in the sediment, at 86 to 95.5 meters and 143 to 152.5 meters sub-bottom, were not cored because the drill bit sank through the soft mud while the downhole temperature measurements were being made. In the sedimentary section cored, recovery was about $75 \%$.

Basement was reached at 232 meters sub-bottom. Drilling in the basement was difficult. Torque was high and variable, and the core bit jammed frequently. Torque was very high even when the bit was not on the bottom, suggesting that hole conditions were poor. The high torque may have been due in part to the unintentional inflation of the rubber packer assembly. During the drilling there was continuous difficulty with the Bowen rotary power unit as well. After penetrating the basement for 9 meters and recovering only a few fragments of basalt, we decided to move to another place to try to find better basement conditions. Operations at Hole 505 finished at about midnight, 1 October 1979.

\section{Hole 505A}

The bit was raised above the mudline, and the vessel was moved 500 meters north. This brought us over the southern flank of a small sediment-covered ridge in the floor of the trough. Hole 505A was spudded at $0255 \mathrm{hr}$. on 2 October in a water depth of 3525 meters. We washed through the sedimentary section, which was entirely unconsolidated ooze, to basement, which was at $196.5 \mathrm{me}-$ ters sub-bottom (Table 1), about 36 meters higher than the basement at Hole 505 .

Torque was very high when we tried to start the basement hole. The first core consisted of a few small pieces of basalt. The rotary power unit continued to break down for extended periods. The drill pipe stuck while we were taking the second core, but we managed to free it by using the torque jar. As a result of these difficulties, we decided to pull up the drill string and inspect the packer assembly and the bit. In total, 12 meters of basement were cored, of which 0.75 meter was recovered (Table 1). When we brought the drill string up to the surface we realized that the inflatable packer element had been completely torn off. The bit was still in good condition. Operations at Hole 505A ended at about midnight on 2 October.

\section{Hole 505B}

In hopes of finding more easily drilled basement, we moved the Glomar Challenger 250 meters north, to the top of a small ridge in the center of the graben. This time the packer was not included in the BHA. Pipe was run in, and Hole 505B was spudded at $1237 \mathrm{hr}$. on $3 \mathrm{Oc}-$ tober in 3507 meters of water. Again the bit was washed through the sedimentary layer, and basement was encountered at 136 meters sub-bottom (Table 1), 48.5 meters higher than at Hole 505A and 128 meters higher than at Hole 505 .

Basement was drilled and cored to $\mathbf{4 2}$ meters below the base of the sediments. Drilling conditions were difficult again. The problems we encountered in drilling basement at Site 505 stemmed from the highly fractured and fresh nature of the basement rocks. Fragments of the walls of the hole readily broke free and jammed the BHA. After 42 meters of basement had been penetrated, conditions in the hole became very difficult, and we 


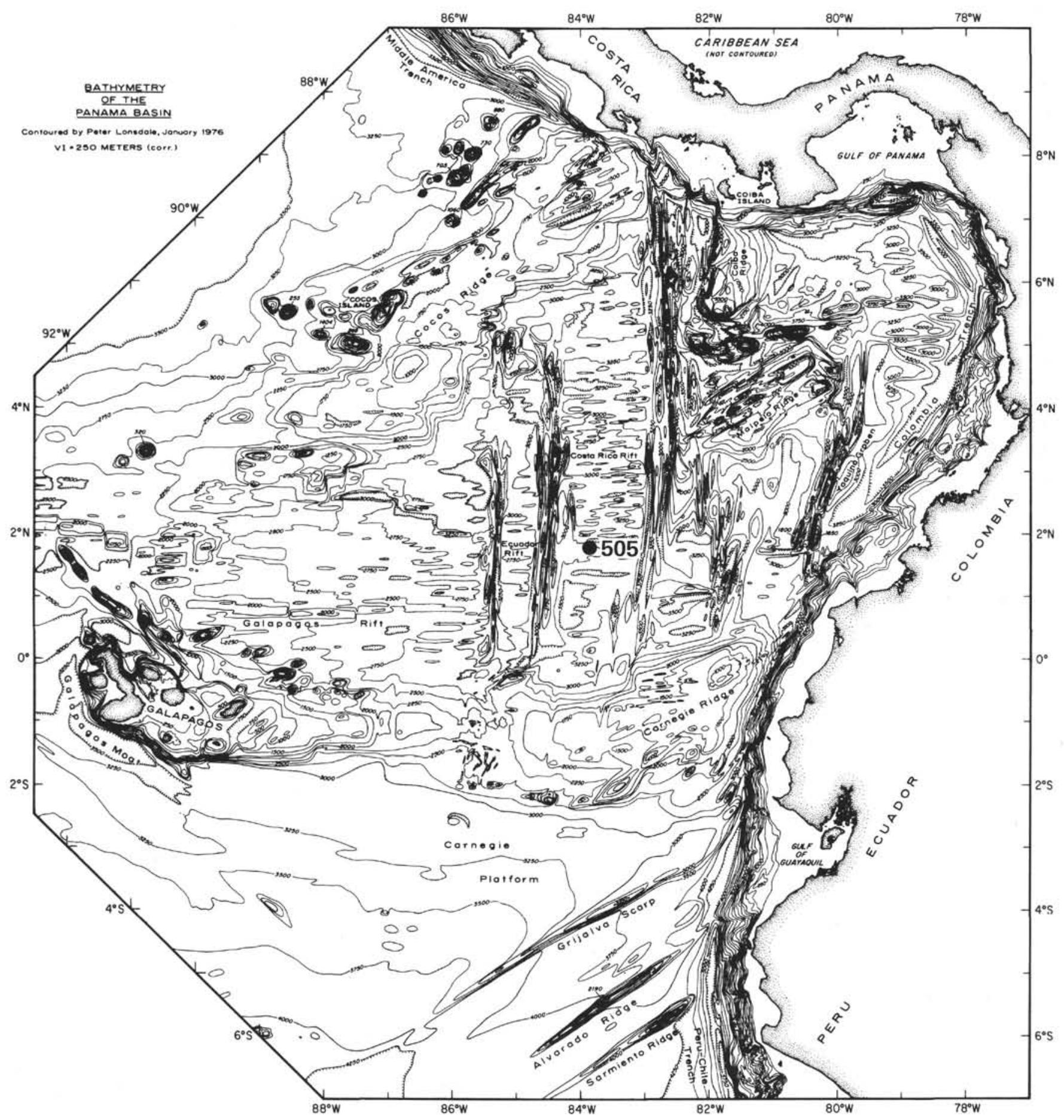

Figure 1. Location of Site 505 near the Costa Rica Rift. Bathymetry from Lonsdale and Klitgord (1978). Contour interval $=250 \mathrm{~m}$.

decided to stop drilling. The hole was flushed with 50 barrels of weighted mud, and the bit was released in preparation for logging.

Three suites of logging tools were run into the hole. The first measured compensated gamma density, caliper, natural gamma rays, and temperature; the second, neutron porosity, guard resistivity, and natural gamma rays. The third took downhole water samples and measured temperature.
While the tools were being lowered through the hole, the bottom hole assembly was lowered so that its end was 1 meter below the sediment/basalt contact. For the logging run itself, which was made while the logging tools were being hoisted up the hole, the pipe was raised 28 meters (one stand).

The first two suites of tools were run very successfully. The third, however, may not have reached the bottom of the hole. The temperature record suggests that the 
Table 1. Coring summary, Site 505.

\begin{tabular}{|c|c|c|c|c|c|c|c|}
\hline Core & $\begin{array}{c}\text { Date } \\
\text { (1979) }\end{array}$ & Time & $\begin{array}{l}\text { Depth from } \\
\text { Drill Floor } \\
\text { (m) }\end{array}$ & $\begin{array}{l}\text { Depth below } \\
\text { Seafloor } \\
\text { (m) }\end{array}$ & $\begin{array}{l}\text { Length } \\
\text { Cored } \\
\text { (m) }\end{array}$ & $\begin{array}{l}\text { Length } \\
\text { Recovered } \\
\text { (m) }\end{array}$ & $\begin{array}{c}\text { Recovery } \\
(\%)\end{array}$ \\
\hline \multicolumn{8}{|c|}{ Hole 505} \\
\hline 1 & 30 Sept. & 0300 & $3548.5-3549.0$ & $0-0.5$ & 0.5 & 0.17 & 34 \\
\hline 2 & 30 & 0430 & $3549.0-3558.5$ & $0.5-10.0$ & 9.5 & 8.90 & 94 \\
\hline 3 & 30 & 0555 & $3558.5-3568.0$ & $10.0-19.5$ & 9.5 & 7.50 & 79 \\
\hline 4 & 30 & 0725 & $3568.0-3577.5$ & $19.5-29.0$ & 9.5 & 10.23 & 108 \\
\hline 5 & 30 & 0900 & $3577.5-3587.0$ & $29.0-38.5$ & 9.5 & 9.52 & 100 \\
\hline 6 & 30 & 1025 & $3581.0-3596.5$ & $38.5-48.0$ & 9.5 & 10.83 & 114 \\
\hline 7 & 30 & 1200 & $3596.5-3606.0$ & $48.0-57.5$ & 9.5 . & 9.05 & 95 \\
\hline 8 & 30 & 1325 & $3606.0-3615.5$ & $57.5-67.0$ & 9.5 & 1.31 & 14 \\
\hline 9 & 30 & 1435 & $3615.5-3625.0$ & $67.0-76.5$ & 9.5 & 5.03 & 53 \\
\hline 10 & 30 & 1553 & $3625.0-3634.5$ & $76.5-86.0$ & 9.5 & 7.03 & 74 \\
\hline- & 30 & 1740 & $3634.5-3644.0$ & $86.0-95.5$ & \multicolumn{3}{|c|}{ Wash-heat flow, pore water } \\
\hline II & 30 & 1852 & $3644.0-3653.5$ & $95.5-105.0$ & 9.5 & 8.83 & 93 \\
\hline 12 & 30 & 1956 & $3653.5-3663.0$ & $105.0-114.5$ & 9.5 & 6.47 & 68 \\
\hline 13 & 30 & 2112 & $3663.0-3672.5$ & $114.5-124.0$ & 9.5 & 9.46 & 100 \\
\hline 14 & 30 & 2225 & $3672.5-3682.0$ & $124.0-133.5$ & $9.5^{\circ}$ & 8.28 & 87 \\
\hline 15 & 30 & 2339 & $3682.0-3691.5$ & $133.5-143.0$ & 9.5 & 8.64 & 89 \\
\hline- & 1 Oct. & 0115 & $3691.5-3701.0$ & $143.0-152.5$ & \multicolumn{3}{|c|}{ Wash-heat flow, pore water } \\
\hline 16 & $i$ & 0250 & $3701.0-3710.5$ & $152.5-162.0$ & 9.5 & 0.02 & 2 \\
\hline 17 & $i$ & 0415 & $3710.5-3720.0$ & $162.0-171.5$ & 9.5 & 10.99 & 115 \\
\hline 18 & $i$ & 0542 & $3720.0-3729.5$ & $171.5-181.0$ & 9.5 & 8.20 & 86 \\
\hline- & 1 & 0720 & 3729.5 & 181.0 & \multicolumn{3}{|c|}{ Wash-heat flow, pore water } \\
\hline 19 & 1 & 0950 & $3729-3739.0$ & $181.0-190.5$ & 9.5 & 11.10 & 117 \\
\hline 20 & 1 & 1030 & $3739.0-3748.5$ & $190.5-200.0$ & 9.5 & 11.00 & 116 \\
\hline 21 & $i$ & 1155 & $3748.5-3758.0$ & $200.0-209.5$ & 9.5 & 11.49 & 120 \\
\hline- & $i$ & 1340 & 3758.0 & 209.5 & \multicolumn{3}{|c|}{ Wash-heat flow, pore water } \\
\hline 22 & 1 & 1450 & $3758.0-3767.5$ & $209.5-219.0$ & 9.5 & 9.58 & 101 \\
\hline 23 & $i$ & 1620 & $3767.5-3777.0$ & $219.0-228.5$ & 9.5 & 9.53 & 100 \\
\hline 24 & $i$ & 1735 & $3777.0-3782.0$ & $228.5-233.5$ & 5.0 & 3.55 & 71 \\
\hline 25 & 1 & 1947 & $3782.0-3786.5$ & $233.5-238.0$ & 4.5 & 0.09 & 2 \\
\hline \multirow[t]{2}{*}{26} & $i$ & 2355 & $3786.5-3790.5$ & $238.0-242.0$ & 4.0 & 0.34 & 9 \\
\hline & \multicolumn{4}{|r|}{ Totals } & 223 & 187.14 & 83.9 \\
\hline
\end{tabular}

Hole 505A
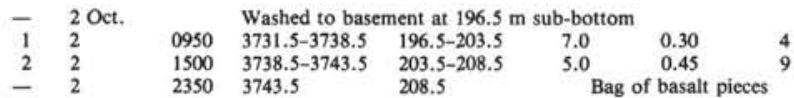

Hole 505B

bottom
5.0
9.5
9.0
4.5
5.0
9.0
42.0

$\begin{array}{rr}0.15 & 3 \\ 2.62 & 28 \\ 1.65 & 18 \\ 0.10 & 2 \\ 0.73 & 14 \\ 1.60 & 17 \\ 6.85 & 16\end{array}$

tool may have lodged in the hole at a depth of about 3661 meters. If so, the $100-\mathrm{ml}$ sample of water that was drawn into the water sampler was taken at that level.

Between the running of the first and second suites of logs two other downhole experiments were attempted. The Soviet downhole magnetometer was run successfully into the hole four times and produced a record of the changes in magnetic susceptibility and the three components of the magnetic field with depth. A borehole televiewer run was tried, but the instrument lost signal near the bottom of the hole. A second run was tried, but at a depth of about 2000 meters the protective sleeve around the transducer imploded, flooding the transducer end of the tool. No further attempts were made to run the televiewer into Hole 505B.

After the logging was completed the BHA was run to the bottom of the hole for the last time and an Eastman Survey was run to determine the inclination of the hole. It indicated that the hole was $2.2^{\circ}$ from vertical. Subsequently the pipe was pulled out of the hole. Operations at Site 505 ended about noon on 7 October 1979.

\section{SEDIMENT LITHOLOGY AND STRATIGRAPHY}

\section{Summary}

The sedimentary column in Hole 505 consists of three lithologic units (Fig. 2): Unit I (0-14.5 m), a late Pleistocene calcareous marl; Unit II (14.5-133.5 m), a late Pliocene to late Pleistocene variably clay-bearing nannofossil siliceous ooze; and Unit III (133.5-232 m), an early to late Pliocene siliceous nannofossil ooze.

Calcareous and siliceous microfossils and clays with montmorillonite as the dominant clay mineral are the major constituents of the sedimentary section. Rhyolitic volcanic glass and pyrite are minor but significant components of nearly all cores. Green hues dominate the sediment colors. A strong smell of hydrogen sulfide in all cores suggests anaerobic bacterial activity. Gas bubbles occurred at depths between 100.35 and 100.50 meters, very likely as a result of the formation of hydrogen sulfide or methane. Coring disturbance, which resulted in diapiric and flow structures in the cores, has destroyed sedimentary structures to a considerable degree. However, judging from the structures that can be seen and comparison to Site 504, the sediments at Site 505 are bioturbated throughout. Only ash layers have sharp boundaries. In the remaining sediments, relict bedding is apparent only in changes in color, carbonate content, and grain-size distribution.

\section{Description of the Lithologic Units}

\section{Unit I (Cores 1-3, 0-14.5 $\mathrm{m}$ below the seafloor)}

Unit I consists of calcareous marl. The prevailing colors are very dark grayish brown for the top 1.7 meters and dark olive gray, grayish olive green, and dusky yellow green for the section below. The grain-size distribution shows that the sediments are composed of $7 \%$ sandsized ( $>63 \mu \mathrm{m}$ ), $39 \%$ silt-sized, and $54 \%$ clay-sized material (visual estimates). The $\mathrm{CaCO}_{3}$ content measured by carbonate bomb averages $26 \%$ and results mainly from calcareous nannofossils; foraminifers are rare and poorly preserved. The siliceous part of the silt-sized and sand fractions consists mainly of radiolarians and diatoms. Silicoflagellates, sponge spicules, and volcanic glass are minor constituents. There is a fairly large proportion $(20-30 \%)$ of chitin fragments in the upper part of the unit, among them identifiable fragments of copepod species. At a depth of 3.9 meters the percentage of colorless volcanic glass increases to $15 \%$. The glass probably represents an ash layer disseminated by bioturbation or drilling. The volcanic glass content of the remaining part of the unit is between 2 and $3 \%$ and is therefore higher than in the underlying units.

\section{Unit II (Cores 3-14, 14.5-133.5 below the seafloor)}

Unit II is a variably clay-bearing nannofossil siliceous ooze. The prevailing colors are dusky yellow green, grayish yellow green, grayish green, and dusky olive gray. From 14.5 to 72 meters the average $\mathrm{CaCO}_{3}$ content is $34 \%$, from 72 to 119 meters it is $25 \%$, and from 119 to 133 meters it is $46 \%$. The clay-sized fraction for 


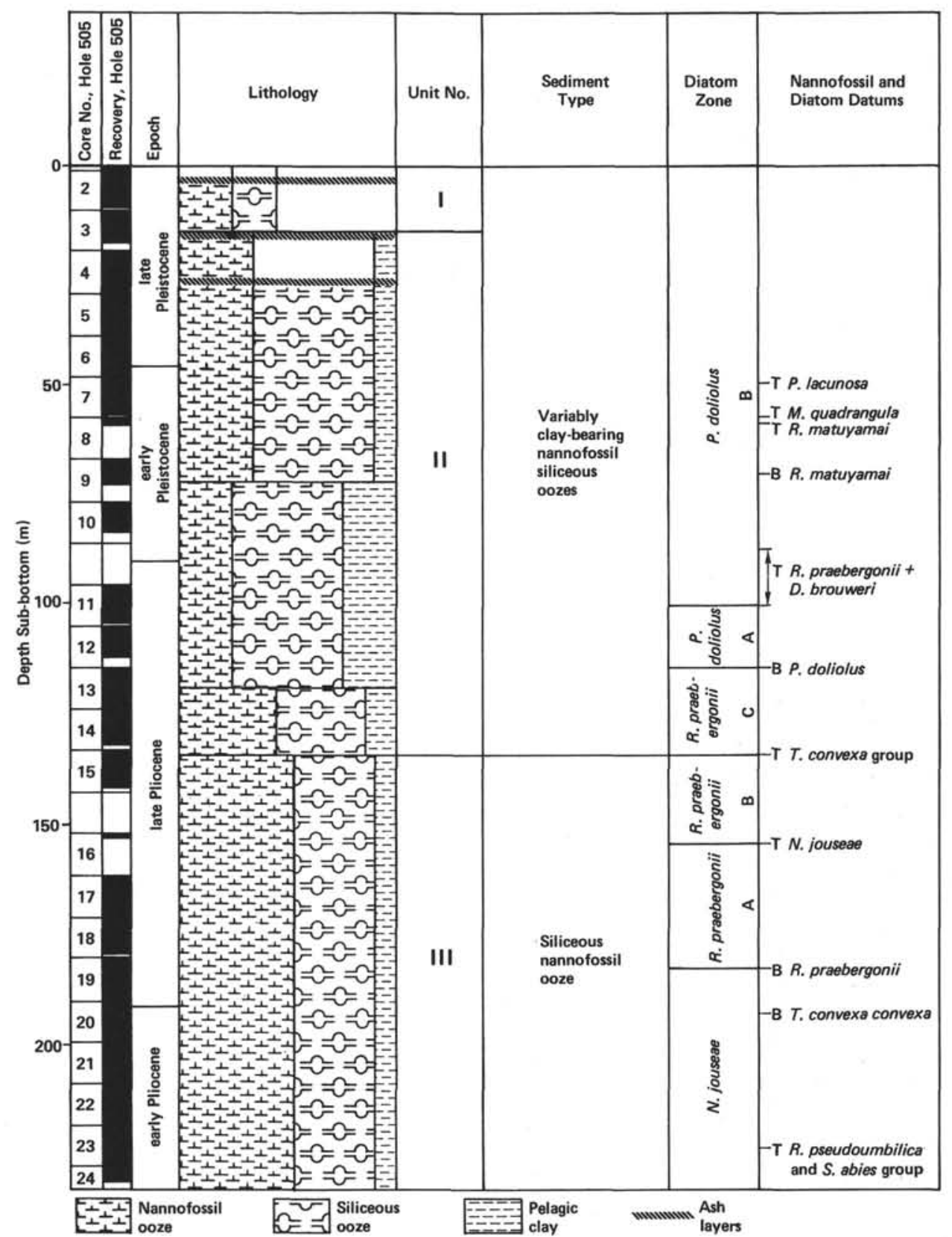

Figure 2. Lithology and diatom biostratigraphy of sediments at Site 505 .

the same intervals averages 10,20 , and $13 \%$. The size of the silt fraction follows the same trend as the clay-sized fraction. The sand-sized fraction for the three intervals varies between 1 and $5 \%$. The components of the different grain-size fractions are essentially the same as in Unit I. There are two volcanic ash layers, one between 16.45 and 16.75 meters and one at 26.40 meters (see also Unit I). However, dispersed volcanic glass exceeds trace amounts (to values between 1 and $2 \%$ ) only in the upper 15 meters of the unit. Zoophycos "spreiten" burrows are common in the upper part of the unit.

\section{Unit III (Cores 15-24, 133.0-232 $\mathrm{m}$ below the seafloor)}

Unit III consists mainly of siliceous nannofossil ooze. The prevailing colors are grayish yellow green to dusky yellow green from 133 to 209 meters and grayish yellow green to pale yellowish green and very pale green from 209 to 232 meters. In the lower part of the interval there is a considerable increase in induration.

The clay-sized fraction decreases continuously with depth, falling from $20 \%$ at the top to $5 \%$ at the base of the unit (average: $8 \%$ ). The sand-sized fraction remains below $8 \%$ without significant variation. The carbonate content ranges between 42 and $73 \%$ (average: 53\%) and generally increases with depth. Pyrite decreases with depth. Grayish blue green (5BG 5/2), dusky blue (5PB $3 / 2$ ), grayish purple (5P $4 / 2$ ), and grayish blue (5PB $5 / 2$ ) tints and streaks are characteristic of Unit III. Before drilling disturbance, these streaks were burrow halos, a few of which were found in spite of the high 
degree of deformation due to the drilling process. At 228.50 meters, 20 to $30 \%$ of the coarse fraction consists of fragments of black to brownish glass. Such glass occurs in only trace amounts in the upper part of the sediment column.

\section{BIOSTRATIGRAPHY}

The Pliocene/Pleistocene boundary (defined by the last occurrence of Rhizosolenia praebergonii and of Discoaster brouweri) apparently falls within the washed interval between Cores 10 and 11 (86-96 m).

The lowest diatom event at Site 505 is the first occurrence of Thalassiosira convexa convexa in Sample 505$19, \mathrm{CC}(190 \mathrm{~m})$, which is here used for the informal division of the early and late Pliocene. The lowest nannofossil event is the extinction of Reticulofenestra pseudoumbilica and of the Sphenolithus abies group, which occurs in the upper part of Core 23 (at $221 \mathrm{~m}$ ). The base of the sediment section must be early Pliocene $(>4.3 \mathrm{Ma})$. Sedimentation rates therefore averaged about $60 \mathrm{~m} / \mathrm{m}$.y.

Figure 2 shows the diatom biostratigraphic zonation and datum levels. A few calcareous nannofossil datums are also given. In some intervals the marker species (especially discoasters and ceratoliths) are rare; the true datum levels for these species cannot be determined.

\section{PHYSICAL PROPERTIES OF SEDIMENT}

Physical property determinations at Site 505 consist of compressional wave seismic velocity measurements (made with the Hamilton frame velocimeter), needle probe measurements of thermal conductivity, and determinations (through gravimetric analysis) of wet bulk density, grain density, water content, and porosity. Measurements were carried out in the least disturbed intervals of the core sections; in cases where complete sections appeared to be disturbed, measurements were generally not carried out. Wilkens and Langseth (this volume) give a complete data presentation in their comparison of Sites 504 and 505. This comparison is of particular interest because the sites are in relatively close proximity ( $80 \mathrm{~km}$ apart) and should have similar sedimentation regimes. Comparison of the physical properties of the two holes also provides an opportunity to compare similar measurements made on sedimentary sections that have been recovered by the hydraulic piston corer (Site 504) and by the standard rotary coring method (Site 505). Of course, another factor that must be taken into consideration in a comparison of the physical properties of the sediments at the two sites is the drastic difference in the heat flow regimes.

\section{Seismic Velocity}

The compressional wave seismic velocities measured at Site 505 are essentially uniform, ranging from 1.49 to $1.53 \mathrm{~km} / \mathrm{s}$. Scatter in the data is greatest in the upper 50 meters of the section and is probably related to the greater degree of drilling disturbance in the highly unconsolidated sediments. The mean velocity of $1.51 \mathrm{~km} / \mathrm{s}$ for the entire section agrees well with the mean velocity of the upper unit in the Site 504 sediments.

\section{Gravimetric Data}

As at Site 504, gravimetric parameters display several large-scale variations down the hole. The correlation between the two sites is excellent and is discussed in detail in Wilkens and Langseth (this volume). In general, wet bulk density tends to increase with depth, varying from values between 1.21 and $1.25 \mathrm{~g} / \mathrm{cm}^{3}$ near the top to values approaching $1.5 \mathrm{~g} / \mathrm{cm}^{3}$ at the bottom. Grain density also increases; porosity and water content decrease.

\section{Thermal Conductivity}

As at Site 504, thermal conductivity varies mainly with porosity and so exhibits local variations at different levels in the core. In general, conductivity increases with depth; the average value is $0.77 \mathrm{~W} / \mathrm{m} \mathrm{K}$ for the upper section of the core and $1.05 \mathrm{~W} / \mathrm{m} \mathrm{K}$ for the 20 meter-thick layer at the bottom. As at Site 504, sediments with values of conductivity greater than $1.00 \mathrm{~W} / \mathrm{m} \mathrm{K}$ generally have lower-than-usual values of resistivity for any given level of water content, suggesting that the thermal conductivity of the solid skeleton of the sediment is different from that of the more unconsolidated sediments.

\section{PORE WATER CHEMISTRY}

The pore water chemistry for the upper 100 meters of the sediment is dominated by the bacterial reduction of sulfate, which has produced an eightfold increase in alkalinity. The increase in alkalinity is accompanied by a reduction in $\mathrm{Ca}^{2+}$ to one-third the seawater value due to calcite precipitation. These trends are reversed below 100 meters, probably because of reactions with the basement. Both alkalinity and $\mathrm{Ca}^{2+}$ approach seawater values near the basement. The level of $\mathrm{Mg}^{2+}$ is very slightly higher in the upper 15 meters of sediment and decreases slightly and gradually from there to basement. An attempt to sample formation water from the basement with the Gearhart-Owen wireline sampler produced a mixture of surface seawater used as drilling fluid and sediment (with interstitial water) that had fallen down the hole. Further details and interstitial water analyses are to be found in chapters by Mottl and others in this volume.

\section{BASEMENT LITHOSTRATIGRAPHY}

\section{Hole 505}

The basement at Hole 505 was penetrated for about 9 meters, but of this only 0.5 meter was recovered. The rock is petrographically uniform, consisting of a highly plagioclase-olivine phyric basalt containing chromespinel and rare emerald green clinopyroxene phenocrysts. The phenocrysts appear rounded and resorbed and are possibly xenocrysts. The groundmass is microlitic and variolitic. Vesicles (which constitute up to $2 \%$ of the rock) are empty or partly filled around the border with smectite. In general the basalt is extremely fresh, with olivine altered to clays only along cracks. The recovered rocks would seem to suggest that the basement here is a 
sequence of fresh pillows and flows or brecciated flows. No cooling margins were recovered. The basalts were too similar to require lithologic subdivision.

\section{Hole 505A}

At Hole 505A basement was penetrated for 12 meters, but only about 0.75 meter of basalt was recovered. There were no chilled margins in the core. The basement appears to be a single basalt flow of sparsely plagioclaseolivine phyric basalt with rare accessory chrome-spinel. Hole 505A basalts differ from those of Hole 505 in having fewer phenocrysts and no phyric clinopyroxene.

\section{Hole 505B}

Basement was penetrated at Hole 505B for 42 meters, and 6.85 meters were recovered. The recovered rocks represent a pillow and flow sequence and are petrographically rather uniform. They are sparsely to moderately plagioclase-olivine phyric basalts with accessory chrome-spinel. The chrome-spinel is scattered in the groundmass, present in chilled glass margins, and occasionally included in phenocrysts of plagioclase and olivine. The groundmass varies from microlitic to variolitic or glassy at the chilled margins. The central parts of the unit are holocrystalline and have an ophitic groundmass of plagioclase, clinopyroxene, olivine, and titanomagnetite.

The basalts from this hole appear almost identical to those recovered from Hole $505 \mathrm{~A}$, both petrologically and geochemically.

\section{BASEMENT IGNEOUS PETROGRAPHY}

The basement recovered from the three holes at Site 505 can be divided into two petrographic groups on the basis of phenocryst concentration and mineral composition. The groups are designated Types $\mathrm{C}$ and $\mathrm{M}$, the letters being mnemonic devices to indicate the basalt's important petrographic features. Type $C$ is sparsely plagioclase-olivine phyric basalt with accessory chrome-spinel. Type $\mathbf{M}$ is strongly plagioclase-olivine-clinopyroxene phyric basalt with accessory chrome-spinel. Emerald green clinopyroxene occurs in Type $\mathrm{M}$ as isolated phenocrysts.

Basalts of Type $\mathrm{C}$ are confined to Holes 505A and 505B; basalts of Type M, to Hole 505. Accordingly, the Type $C$ basalts will be dealt with under a single heading, Type $M$ basalts under another.

\section{Holes 505A and 505B}

Basalts from Holes 505A and 505B appear as a series of fine- to medium-grained sparsely phyric rocks. Basalts defined as Type $\mathrm{C}$ for Site 505 can be considered identical to the basalts defined as Type C for Site 504, except that phenocrysts are more abundant at Site 505. The phenocrysts are plagioclase and olivine; clinopyroxene is present only in the groundmass.

The plagioclase phenocrysts, which constitute 4 to $5 \%$ of the rock, occur as single crystals and as glomerocrysts. In size the glomerocrysts are comparable to the single crystals (maximum diameter: $2.5-3.0 \mathrm{~mm}$; average: $1.5-$ $2.0 \mathrm{~mm}$ ), but they are composed of an aggregate of sev- eral smaller grains. The grains can be either euhedral or subhedral, and they occasionally enclose granular olivine grains. Most of the macroscopic plagioclase is in the form of single phenocrysts.

Individual plagioclase grains show a greater range in size $(0.5-3.2 \mathrm{~mm})$ than the glomerocrysts $(1.5-3.0 \mathrm{~mm})$. They also have a more variable texture. Most of the phenocrysts are euhedral or subhedral, but there are occasional resorbed anhedral forms. In the center of a few of the larger phenocrysts there is a zone of small glass inclusions, many of which contain a gas bubble. Very rarely the phenocrysts have dendritic margins, with each dendrite acting as a nucleus for spherulite crystal growth. This nucleation is less pronounced in pillow margins because of the greater degree of undercooling, which suppresses dendrite formation.

Both the glomerocrysts and the phenocrysts are of the same composition, varying between $\mathrm{An}_{80}$ and $\mathrm{An}_{92}$ (average: $\mathrm{An}_{88}$ ). Pronounced zoning is common, the crystals becoming more sodic toward their rims, where values are between $\mathrm{An}_{60}$ and $\mathrm{An}_{89}$.

Olivine phenocrysts $\left(\mathrm{Fo}_{87-89}\right)$ form 2 to $3 \%$ of the basalt. They occur as euhedral and subhedral grains of variable size (maximum: $0.8-1.0 \mathrm{~mm}$; average: $0.2-0.4$ $\mathrm{mm})$. The groundmass crystals occasionally form glomerocrysts of phenocryst size. There are a few cases in which anhedral olivine grains are enclosed within plagioclase phenocrysts. The olivine in these basalts is usually fresh, and alteration down cracks is minor or absent. It is rare to find olivines that are completely replaced by clays.

The groundmass textures in these basalts are similar to those in the Type $\mathrm{M}$ basalts, containing acicular skeletal plagioclase in a dendritic spherulitic matrix ( 50 $75 \%$ ) that is dusted with opaques. The groundmass is microlitic in a mesostasis of spherulitic crystals in glass. The proportion of microlites to mesostasis is variable but appears to be dependent on the grain size of the basalt. Microlites may make up $45 \%$ of the coarser interiors of pillows and flows and $15 \%$ of the marginal areas. They vary correspondingly in size (length: $0.05-1.5 \mathrm{~mm}$ ), but their morphology is constant (almost always dendritic and skeletal). There is no flow orientation. Most of the microlites are plagioclase $\left(\mathrm{An}_{55-79}\right)$; olivine microlites occur but are rare.

The mesostasis, which forms the remainder of the rock $(50-55 \%)$, is composed of spherulitic crystals in glass. In the fine-grained rocks individual crystals cannot be distinguished from the brown volcanic glass and opaques, but in the coarser-grained rocks and where the glass has been altered to light-colored clays, the crystals ( $0.02 \mathrm{~mm}$ in size) can be seen to be composed of pale brown clinopyroxene and plagioclase. Spherulite fans often show bow-tie and radial structures, and plagioclase microlites commonly act as nuclei.

The minerals pyrite, titanomagnetite, and chromespinel form $\sim 2 \%$ of the rock. Pyrite occurs as euhedral or skeletal grains and as drawn-out aggregates forming minor veining, all in close proximity to vesicles (secondary?). Trace quantities of submicroscopic pyrite are disseminated in the mesostasis (primary?). Titanomagnetite 
is euhedral, subhedral, and skeletal; it is highly disseminated and generally submicroscopic. In pillow margins the grains are sometimes preferentially concentrated around the periphery of spherulites. Isolated euhedral chrome-spinel crystals (traces only, in Hole 505A) are skeletal, vermicular, or (more commonly) homogeneous. Chrome-spinel grains can occur within olivine and plagioclase phenocrysts but are not common.

\section{Hole 505}

Basalts from Hole 505 belong to a single petrographic group (Type $\mathrm{M}$ ) and are strongly plagioclase-olivine phyric, with some clinopyroxene phenocrysts and accessory chrome-spinel. The phenocrysts vary widely in morphology and compose up to $30 \%$ of the basalt. In total, $20 \%$ of the crystals may be plagioclase and $5 \%$ may be olivine; the clinopyroxene crystals are occasional.

Plagioclase occurs as phenocrysts and glomerocrysts of variable size (maximum length and diameter: 2.5 $\mathrm{mm}$; average: $1.5-2.0 \mathrm{~mm}$ ). Its composition is $\mathrm{An}_{75-92}$. Pronounced zoning toward more sodic rims is common. Anhedral glass inclusions occur in the cores of several crystals. Less common are ophitic plagioclase megacrysts that contain inclusions of anhedral olivines and chrome-spinel. Partially resorbed feldspar phenocrysts are sometimes evident.

Olivine $\left(\mathrm{Fo}_{87-89}\right)$ is present as euhedral or subhedral phenocrysts, some of which are skeletal, and as glomerocrysts. The phenocrysts are 1.0 to $2.5 \mathrm{~mm}$ in size. The glomerocrysts are often ophitic or subophitic, the grains containing inclusions of plagioclase. Blue and green smectites partially replace the larger olivine phenocrysts and all of the groundmass olivine.

There are a few clinopyroxene phenocrysts; they are generally anhedral and twinned (1.0-4.0 mm long). Their rounded and corroded appearance suggests a degree of resorption. In hand specimen they appear as bright emerald green crystals.

Chrome-spinel, pyrite, and titanomagnetite form $\sim 2 \%$ of the basalt. The chrome-spinel occurs as large euhedral grains, both vermicular and skeletal. The grains often appear within phenocrysts of plagioclase and olivine. Pyrite is limited to veining and is consequently secondary. Submicroscopic euhedral grains of titanomagnetite are disseminated in the mesostasis.

\section{BASEMENT CHEMISTRY}

The difference between the petrography of the basalts in Hole 505, on the one hand, and Holes 505A and 505B, on the other, is reflected in the chemistry of these basalts. Shipboard X-ray fluorescence (XRF) measurements (Etoubleau et al., this volume) indicate that samples from Holes 505A and 505B have higher contents of $\mathrm{TiO}_{2}, \mathrm{Fe}_{2} \mathrm{O}_{3}, \mathrm{Na}_{2} \mathrm{O}$, and $\mathrm{Zr}$ and lower contents of $\mathrm{Al}_{2} \mathrm{O}_{3}$, $\mathrm{MgO}, \mathrm{CaO}, \mathrm{Ni}$, and $\mathrm{Sr}$ than basalts from Hole 505 (Table 2).

Basalts from Holes 505A and 505B are mafic, but not enough so to have originated as direct melts from the mantle. Their $\mathrm{Mg} /(\mathrm{Mg}+\mathrm{Fe})$ ratios $(0.641$ and 0.647$)$ and $\mathrm{Ni}$ contents (151 and $161 \mathrm{ppm})$ are low compared with the $\mathrm{Mg} /(\mathrm{Mg}+\mathrm{Fe})$ ratio of 0.70 and $\mathrm{Ni}$ content of
Table 2. Average chemical composition of Site 505 basalt.

\begin{tabular}{lrrr}
\hline & $\begin{array}{r}\text { Hole } \\
505 \mathrm{a}\end{array}$ & $\begin{array}{r}\text { Hole } \\
505 \mathrm{~A}^{\mathrm{a}}\end{array}$ & $\begin{array}{r}\mathrm{Hole} \\
505 \mathrm{~B}^{\mathrm{b}}\end{array}$ \\
\hline \multicolumn{2}{c}{ Major elements (wt. \%) } & & \\
$\mathrm{SiO}_{2}$ & 48.24 & 49.03 & 49.67 \\
$\mathrm{TiO}_{2}$ & 0.74 & 0.95 & 0.96 \\
$\mathrm{Al}_{2} \mathrm{O}_{3}$ & 17.45 & 16.05 & 16.08 \\
$\mathrm{Fe}_{2} \mathrm{O}_{3}$ & 8.70 & 9.71 & 9.48 \\
$\mathrm{MnO}$ & 0.14 & 0.15 & 0.15 \\
$\mathrm{MgO}$ & 9.37 & 8.67 & 8.70 \\
$\mathrm{CaO}$ & 13.32 & 12.70 & 12.68 \\
$\mathrm{Na} 2$ & 1.76 & 2.16 & 2.12 \\
$\mathrm{~K}_{2} \mathrm{O}$ & 0.07 & 0.04 & 0.05 \\
$\mathrm{P}_{2} \mathrm{O}_{5}$ & 0.09 & 0.08 & 0.08 \\
$\mathrm{H}_{2} \mathrm{O}$ & 0.73 & 0.68 & 0.75 \\
$\mathrm{CO}_{2}$ & 0.13 & 0.08 & 0.10 \\
$\mathrm{Total}$ & 100.24 & 100.30 & 100.82
\end{tabular}

Trace elements (ppm)

\begin{tabular}{lccc}
$\mathrm{Ni}$ & 188 & 151 & 161 \\
$\mathrm{Sr}$ & 85 & 77 & 77 \\
$\mathrm{Zr}$ & 45 & 54 & 56 \\
$\mathrm{Mg} / \mathrm{Mg}+\mathrm{Fe}$ & 0.696 & 0.641 & 0.647 \\
$\mathrm{Ca} / \mathrm{Ca}+\mathrm{Al}$ & 0.410 & 0.419 & 0.418 \\
\hline
\end{tabular}

a Two analyses apiece used for averages.

b Eight analyses used for average.

$250 \mathrm{ppm}$ for basalt presumed to derive directly from mantle. The $\mathrm{TiO}_{2}$ and $\mathrm{Zr}$ contents $(0.95 \%$ and $55 \mathrm{ppm})$ are lower than in typical mid-ocean-ridge basalts. The mafic character of the basalt derives from the phenocryst phases.

The basalts from Site 505 are less evolved than is common in fast-spreading ridges. (The degree of evolution is usually greater in fast- than in slow-spreading ridges.) Other samples of relatively unevolved lavas from fast-spreading ridges are known, however.

\section{BASEMENT ALTERATION}

Oxidized zones along cracks are the only visible sign of alteration. Four color zones typically occur as one proceeds from cracks to the interior of the basalt: dark gray, yellow, red, and light gray. The oxidation boundaries are sharp-vesicles are filled with a blue green clay in the light gray basalt and with orange or red clay in the red and yellow zones.

In thin section, plagioclase and clinopyroxene are fresh; olivine is partially altered to yellow smectite around rims and along cracks that cut across fresh cores. Vesicles are filled with yellow brown clay minerals in the light gray zone, yellow and red clay minerals in the red zone, and green smectites in the dark gray zone.

Carbonates and phillipsite are present in small amounts in the basalts of all three holes.

The chemical composition of the light gray basalt and basalt that is more altered is given in Table 3. The altered zone has a higher content of total iron and $\mathrm{K}_{2} \mathrm{O}$ and a lower content of $\mathrm{MgO}$ than the light gray basalt (see Noack, this volume). The $\mathrm{Sr}$ content of the altered basalt is also higher, probably as a result of the replace- 
Table 3. Chemical composition of adjacent lessand more-altered basalt in Hole 505B (shipboard XRF data; Etoubleau et al., this volume).

\begin{tabular}{|c|c|c|}
\hline & $\begin{array}{c}\text { Light Gray } \\
\text { Basalt, } \\
\text { Sample } 505 \mathrm{~B}-2-3 \\
(51-52 \mathrm{~cm})\end{array}$ & $\begin{array}{l}\text { Altered Basalt, } \\
\text { Sample 505B-2-3 } \\
(78-87 \mathrm{~cm})\end{array}$ \\
\hline \multicolumn{3}{|c|}{ Major elements (wt.\%) } \\
\hline $\mathrm{SiO}_{2}$ & 49.62 & 49.70 \\
\hline $\mathrm{TiO}_{2}^{2}$ & 0.96 & 0.96 \\
\hline $\mathrm{Al}_{2} \mathrm{O}_{3}$ & 16.05 & 16.24 \\
\hline $\mathrm{Fe}_{2} \mathrm{O}_{3}$ & 9.36 & 9.64 \\
\hline $\mathrm{MnO}$ & 0.14 & 0.18 \\
\hline $\mathrm{MgO}$ & 8.89 & 7.72 \\
\hline $\mathrm{CaO}$ & 12.63 & 12.89 \\
\hline $\mathrm{Na}_{2} \mathrm{O}$ & 2.17 & 2.46 \\
\hline $\mathrm{K}_{2} \mathrm{O}$ & 0.03 & 0.16 \\
\hline $\mathrm{P}_{2} \mathrm{O}_{5}$ & 0.08 & 0.09 \\
\hline $\mathrm{H}_{2} \mathrm{O}$ & 0.97 & 1.03 \\
\hline $\mathrm{CO}_{2}$ & 0.14 & 0.18 \\
\hline \multicolumn{3}{|c|}{ Trace elements (ppm) } \\
\hline $\mathrm{Ni}$ & 160 & 154 \\
\hline $\mathrm{Sr}$ & 74 & 109 \\
\hline $\mathrm{Zr}$ & 53 & 56 \\
\hline
\end{tabular}

ment of olivine or saponitic clays by $\mathrm{Fe}$ - and $\mathrm{K}$-rich clay minerals.

The low temperature measured at the site (Langseth et al., this volume) and the short time since the eruption of the lavas on the seafloor (3.9 Ma) have not permitted great development of alteration. Potassic layer/lattice silicates are absent entirely.

\section{BASEMENT STRUCTURE}

The low recovery of the basement basalts at Site 505 precludes a detailed analysis of basement structure. However, certain inferences can usually be drawn about basement structure from the glass rinds, fractures, and alteration rinds in the basalt.

Glassy and spherulitic pieces are present in every core. The lack of recovery of consecutive oriented pieces longer than $20 \mathrm{~cm}$ indicates that flows or pillows more than 1 meter thick were not cored.

The number of fractures in oriented rock pieces is too small to infer much about the direction and abundance of fractures in situ.

Overall, the basement section is probably a composite of small pillows or flat pillowlike lobes and sheet flows. The occurrence of vertical fractures and vertical alteration rinds implies a predominantly horizontal array of cooling units with vertical and nearly vertical joints. The material is very similar in these respects to basalts recovered from the Eastern Pacific during Legs 34 and 54, where the drilling was as difficult as at Site 505.

\section{BASEMENT PHYSICAL PROPERTIES}

Measurements of the physical properties of the basalt at Site 505 were few because of poor recovery. Velocity minicores with a mean porosity of $6.4 \%$ and a wet bulk density of $2.86 \mathrm{~g} / \mathrm{cm}^{3}$ yielded a mean seismic velocity of
$5.89 \mathrm{~km} / \mathrm{s}$. Measurements of thermal conductivity had a mean of $1.74 \mathrm{~W} / \mathrm{m} \mathrm{K}$. Complete data for Site 505 are presented in Wilkens and Karato (this volume), along with data for Site 504 . The high density values indicate an extremely fresh mineralogy for these basalts, which explains the relatively high seismic velocities.

\section{BASEMENT PALEOMAGNETISM}

The results of magnetic measurements and alternating field (AF) demagnetization with respect to sampling position in Hole 505B are listed in Table 4 and shown in Figure 3 . The intensity, susceptibility, and median demagnetizing field (MDF) of the basalts in this hole are reasonably representative of the values obtained by DSDP for other oceanic basalts. The results of the magnetic measurements are as follows:

1) The average intensity of natural remanent magnetization (NRM) is approximately $1 \times 10^{-2} \mathrm{emu} / \mathrm{cc}$.

2) The mean inclination of the NRM of the basalts is low compared with the average inclination of the present dipole field.

3) The inclinations of the basalts before and after AF demagnetization differ by less than $4^{\circ}$.

The results of microscopic observation are listed in Table 5. Throughout the hole the magnetic minerals are relatively small. Both subhedral and euhedral skeletal shapes occur. Very small amounts of sulfide minerals were found in 11 samples.

\section{EXPERIMENTS AND LOGGING}

Despite the poor penetration at Site 505, experiments were attempted in the hole for comparison with the measurements at Sites 501 and 504. In situ temperature and water samples were obtained, the downhole magnetometer was deployed, and a set of logs was run.

Measurements of in situ temperature were made in the sediment in Hole 505 at depths of $86,143,181$, and 210 meters. All four of these measurements were successful, although while the shallowest measurement was being made the drill bit and probe sank in the sediment for nearly 10 meters, and the probe may have been heated somewhat by friction. Short, apparently frictional disturbances affected the other measurements but did not prevent an accurate reading of in situ water temperature. The temperatures were all low; the thermal gradient was only $2^{\circ} \mathrm{C}$ per 100 meters, which extrapolates

Table 4. Paleomagnetic data, Hole 505B.

\begin{tabular}{lcccrrrr}
\hline $\begin{array}{c}\text { Sample } \\
\text { (core-section, } \\
\text { interval) }\end{array}$ & $\begin{array}{c}\text { Sub-bottom } \\
\text { Depth } \\
(\mathrm{m})\end{array}$ & $\mathrm{MDF}^{\mathrm{a}}(\mathrm{Oe})$ & $\begin{array}{c}\mathrm{K} \text { ) } \\
\text { (cgs } \\
\text { units) }\end{array}$ & $\begin{array}{c}\text { Inclination } \\
\text { before, after } \\
\text { Demagnetization } \\
\left({ }^{\circ}\right)\end{array}$ & $\begin{array}{c}\text { Intensity } \\
\left(\times 10^{-6}\right. \\
\text { emu/cc) }\end{array}$ & $\mathrm{Qn}^{\mathrm{c}}$ \\
\hline $2-1,115-117$ & 142.1 & 170 & 403 & $-10.5,-12.3$ & 6,691 & 47 \\
$2-2,81-83$ & 143.3 & 500 & 176 & 14.9, & 14.7 & 10,993 & 215 \\
$3-1,114-116$ & 151.6 & 280 & 228 & $-10.5,-12.2$ & 14,161 & 177 \\
$3-2,86-88$ & 152.8 & 180 & 301 & $-10.7,-13.0$ & 8,765 & 83 \\
$4-1,10-12$ & 159.6 & 220 & 557 & 1.7, & 1.5 & 15,805 & 81 \\
$5-1,31-33$ & 164.3 & 150 & 723 & $-7.1,-10.0$ & 12,001 & 47 \\
$6-1,109-111$ & 170.1 & 130 & 740 & $0.2,-3.5$ & 8,400 & 32 \\
$6-2,6-8$ & 170.6 & 360 & 380 & $-9.0,-10.0$ & 10,680 & 80 \\
\hline
\end{tabular}

a Median demagnetizing field.

bagnetic susceptibility.

c Königsberger ratio. 

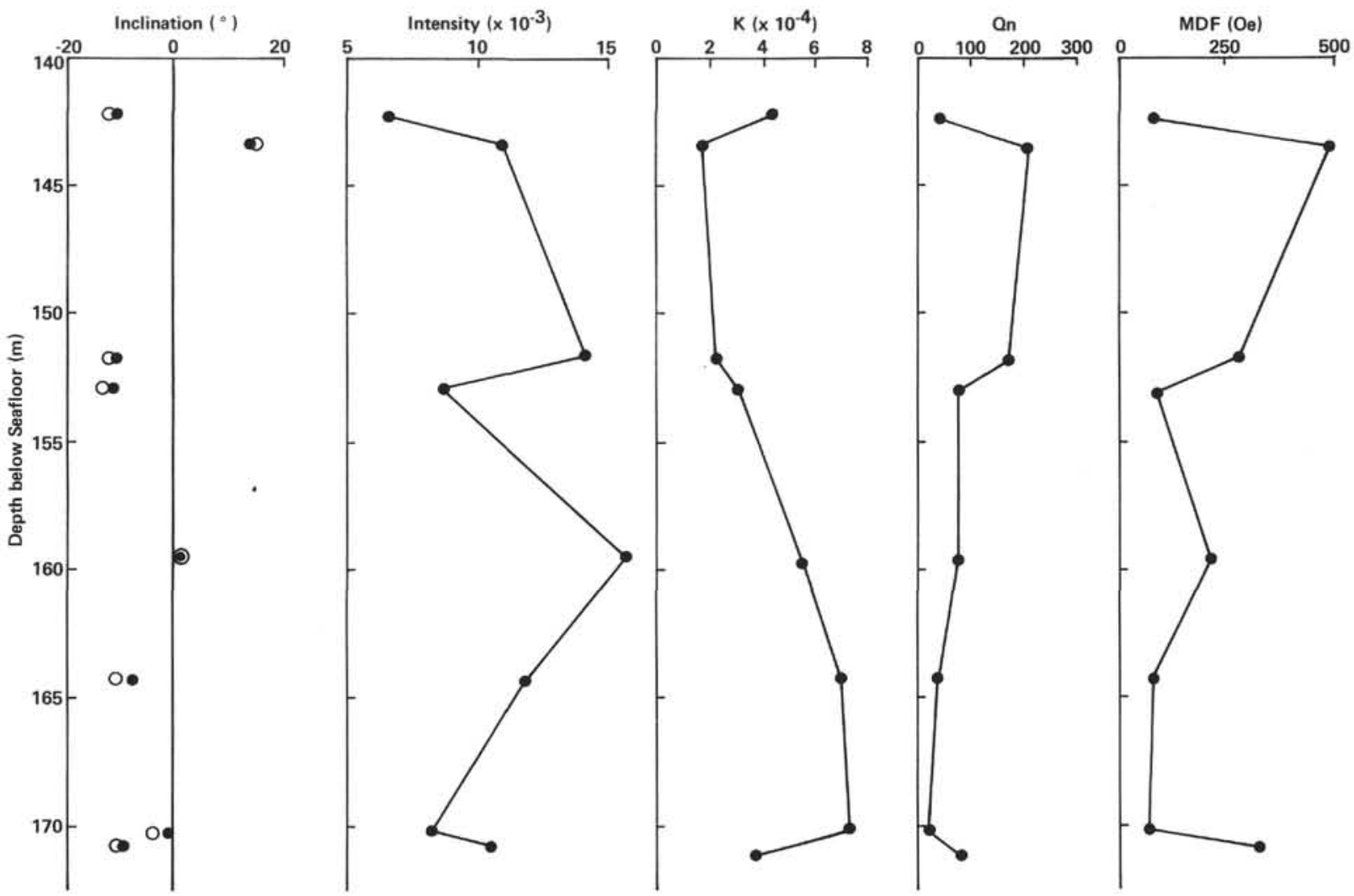

Figure 3. Paleomagnetic properties of Hole 505B basalts. Open circles, initial measurement; filled circles, measurement after demagnetization.

Table 5. Petrographic summary of opaque mineralogy of basalts, Hole 505B.

\begin{tabular}{|c|c|c|c|}
\hline \multirow{2}{*}{$\begin{array}{c}\text { Sample } \\
\text { (core-section, } \\
\text { interval) }\end{array}$} & \multicolumn{2}{|c|}{ Titanomagnetite } & \multirow[b]{2}{*}{ Remarks } \\
\hline & Shape & Grain Size & \\
\hline $2-1,108-111$ & Subhedral & $<5 \mu \mathrm{m}$ & - \\
\hline $2-1,98-101$ & $\begin{array}{l}\text { Subhedral } \\
\text { Skeletal }\end{array}$ & $\begin{array}{c}\operatorname{Max} .30 \mu \mathrm{m} \\
10 \sim 15 \mu \mathrm{m}\end{array}$ & - \\
\hline $3-1,76-79$ & Subhedral & $<5 \mu \mathrm{m}$ & - \\
\hline $3-2,99-101$ & $\begin{array}{l}\text { Subhedral } \\
\text { Skeletal }\end{array}$ & $\begin{array}{l}\text { Max. } 20 \mu \mathrm{m} \\
\quad<10 \mu \mathrm{m}\end{array}$ & - \\
\hline $5-1,43-45$ & Subhedral & $\begin{array}{c}\text { Max. } 50 \mu \mathrm{m} \\
10-20 \mu \mathrm{m}\end{array}$ & - \\
\hline $6-1,112-114$ & Skeletal & $20-30 \mu \mathrm{m}$ & Ilmenite \\
\hline
\end{tabular}

Note: Rock in all samples was olivine-plagioclase basalt. Sulfide was rare.

to only $8.95^{\circ} \mathrm{C}$ at basement. Calculated heat flow was low (18-45 $\left.\mathrm{mW} \mathrm{m}^{-2}\right)$.

In situ water samples were obtained with each temperature measurement. Sixteen additional pore water samples were obtained by squeezing sediments recovered by coring from Hole 505, and one rather muddy sample was brought up in the Gearhart-Owen water sampling tool as part of one of the logging runs in Hole 505B. Chemical analyses of these samples are presented and discussed by Mottl et al. (this volume).
The downhole magnetometer was deployed during the logging of Hole 505B. Magnetic susceptibility and the three components of the magnetic field were measured in the lower 25 meters of sediment and the 42 meters of basement successfully penetrated. The horizontal components of the magnetic field were not measured well over most of the section, because, except for the upper 10 meters of basement, the hole was too close to vertical for the gimballed orientation device to settle in a constant direction. Based on the vertical component alone, however, the basalts are reversely magnetized. Magnetic susceptibility measurements in the sediments gave low and variable results, whereas in the basalts values ranged between 400 and $800 \times 10^{-6} \mathrm{cgs}$ unit. Below the sediment/basalt contact the vertical component of the field increased abruptly to a value approximately 3000 gammas greater than the value for the sediments. Ponomarev and Nekhoroshkov (this volume) discuss these results in greater detail.

Three sets of logs were run in Hole 505B: (1) compensated gamma density, caliper, natural gamma, and temperature logs; (2) neutron porosity, resistivity, and natural gamma logs; and (3) the temperature log, which was run at the same time as the water sampler. In addition, an inclinometer survey was run; it showed the hole to deviate from the vertical by $2.2^{\circ}$ at the bottom of the hole. The interval logged ranged from 15 meters above the top of the basalt to 35.5 meters into basement. Below that 
depth the hole was not accessible to logs. The caliper log showed the hole to be rather irregular, and the porosity and related logs showed great variability in porosity on a scale of meters, with some intervals showing porosities as low as $10 \%$ and others porosities of about $50 \%$. This we interpret to be the result of alternations of pillows, thin flows, breccias, and void spaces in the hole. The natural gamma log was generally smooth, but a large peak was observed immediately above the basalt contact, reaching 50 API units. The logs are discussed further in the chapter by Cann and Von Herzen (this volume).

\section{REFERENCE}

Lonsdale, P., and Klitgord, K. (1978). Structure and tectonic history of the eastern Panama Basin. Geol. Soc. Amer. Bull., 89:981-999. 


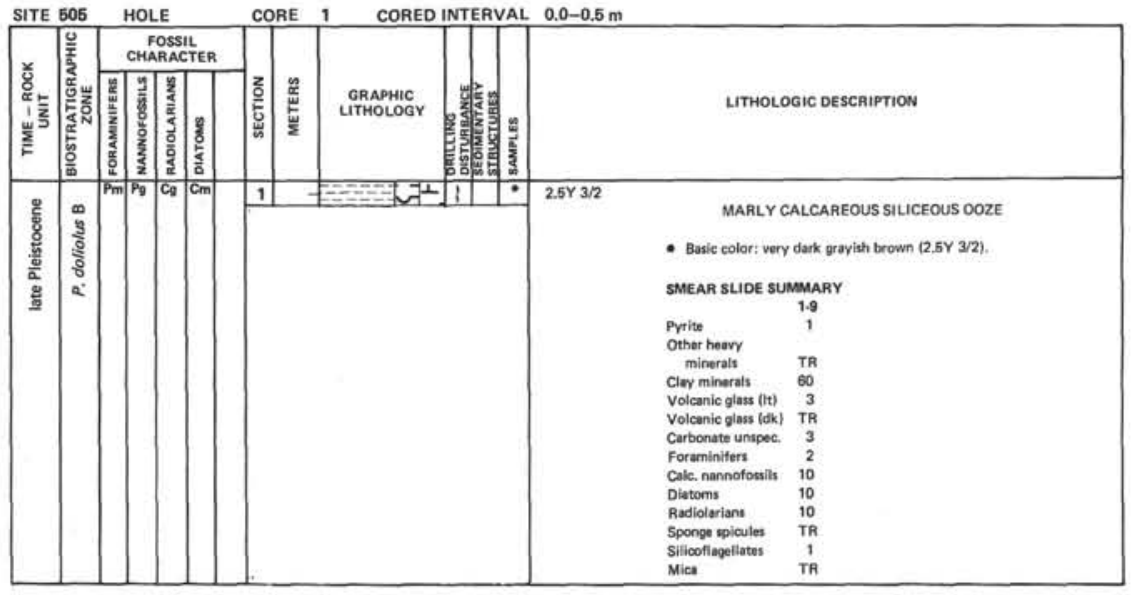

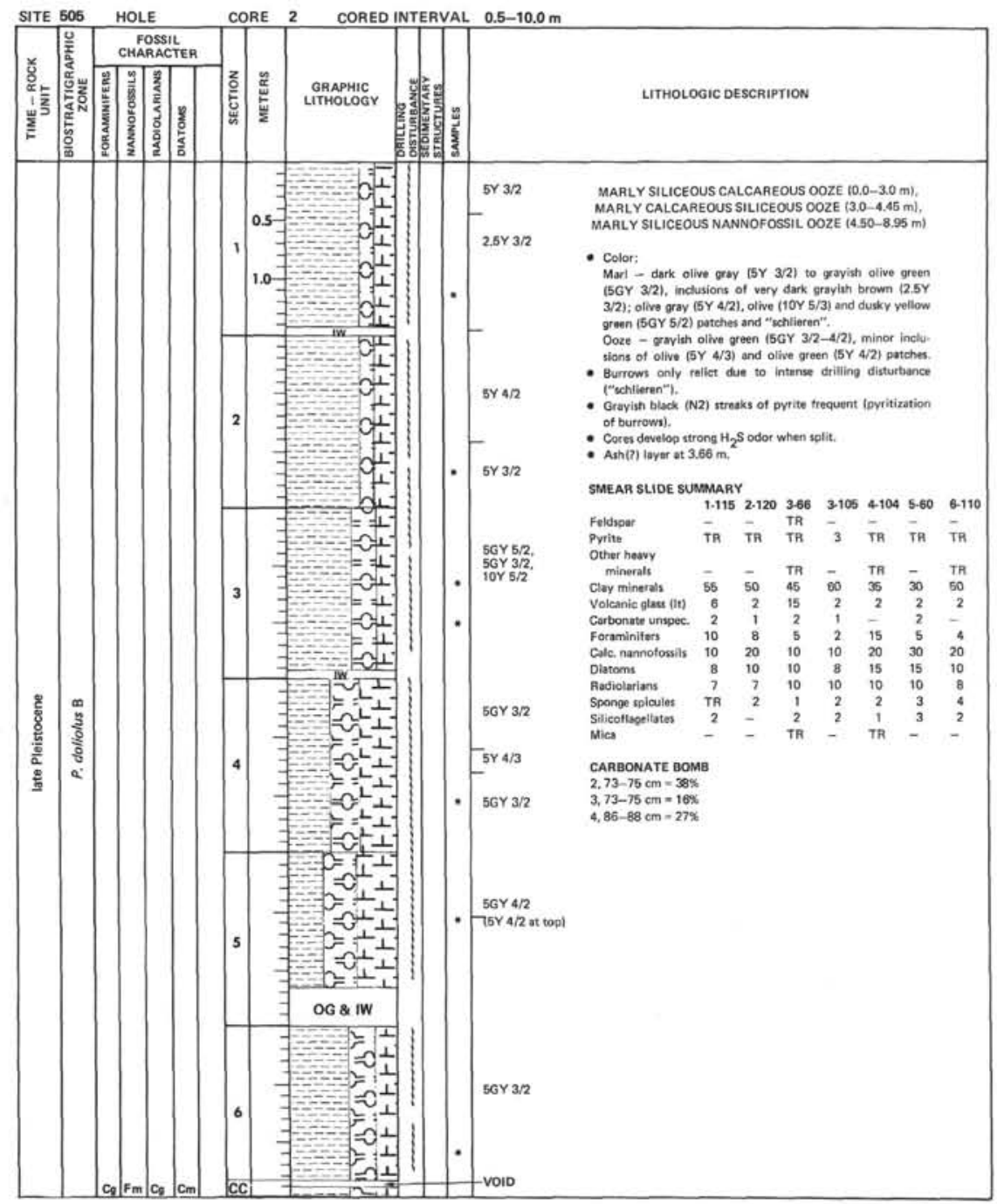



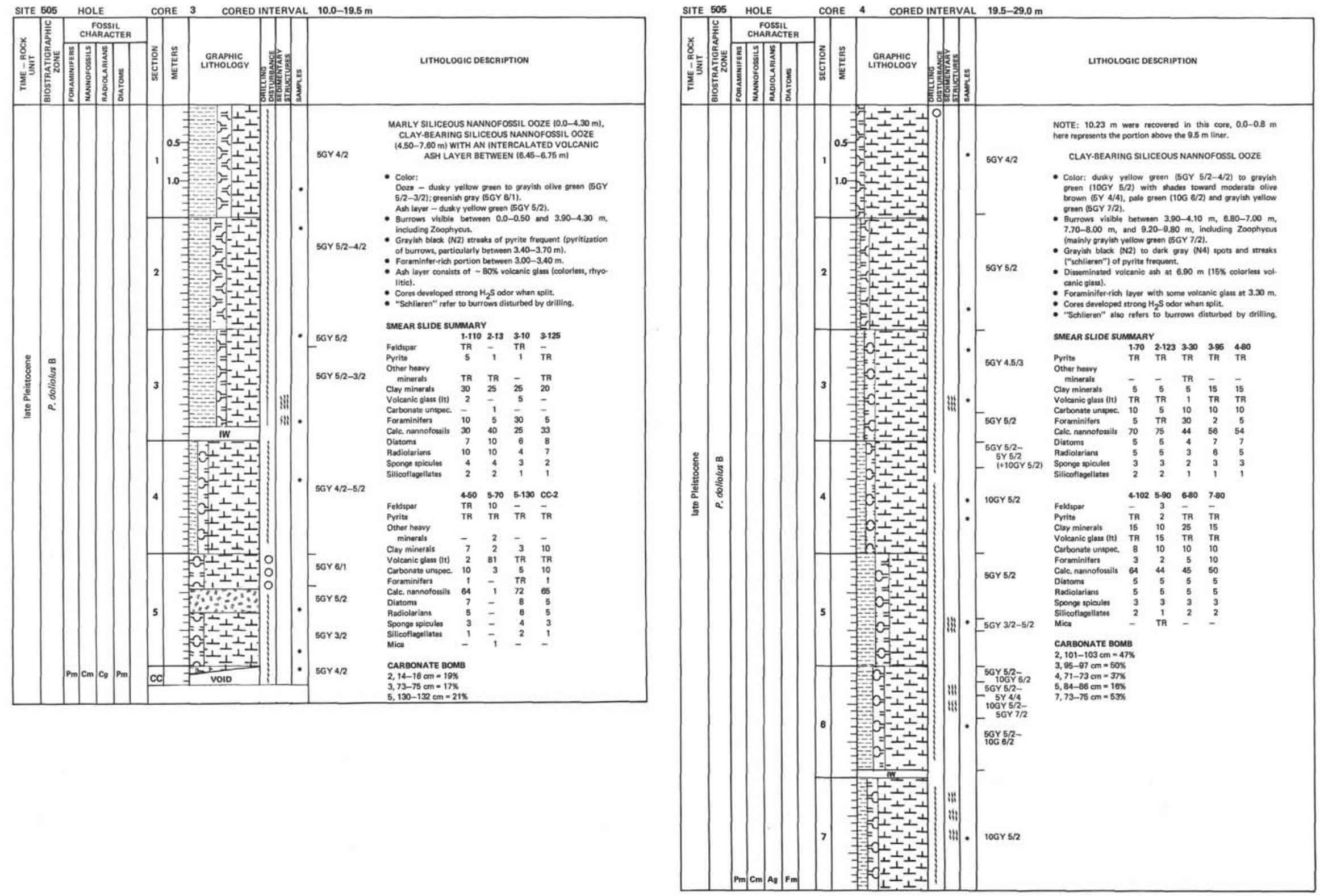


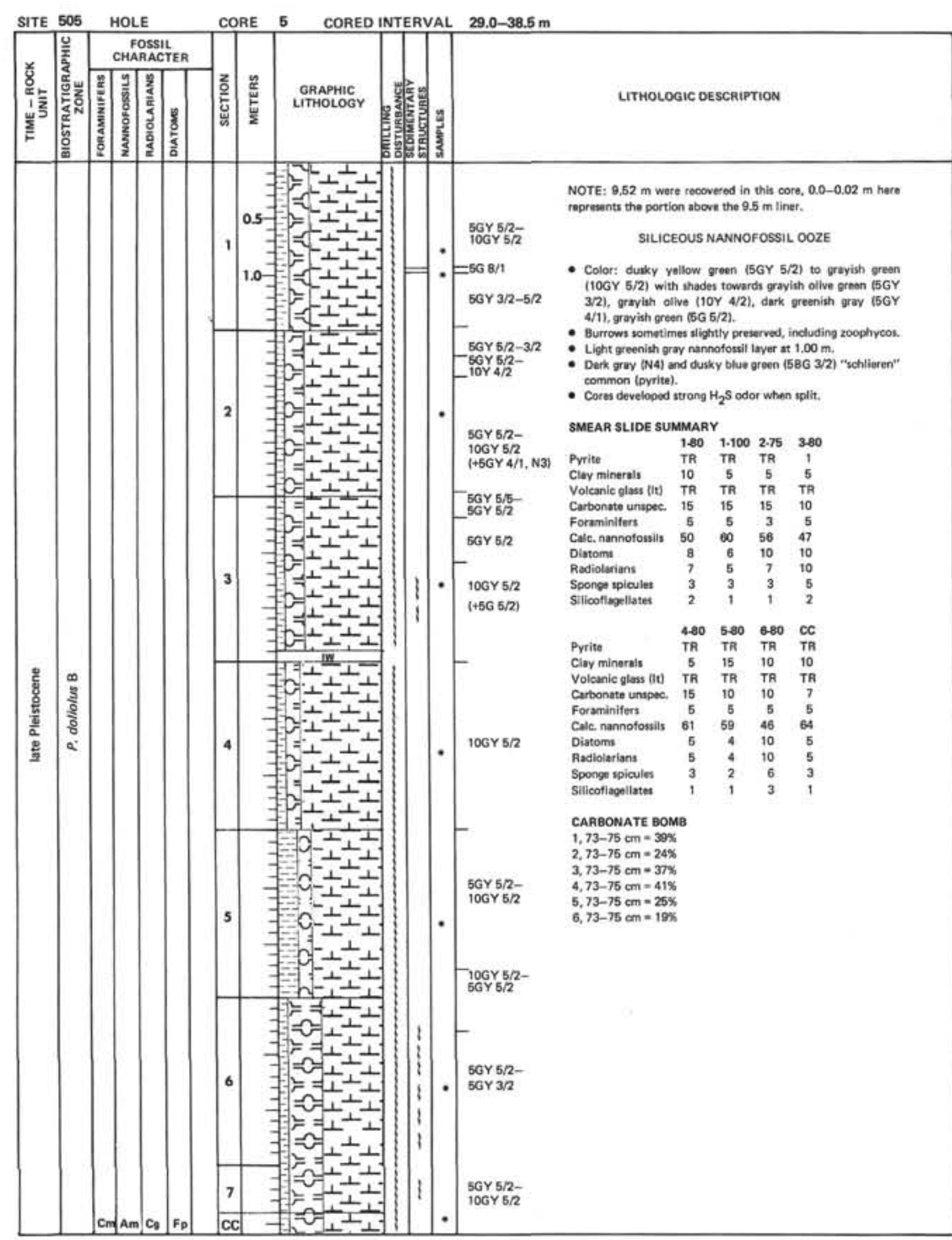

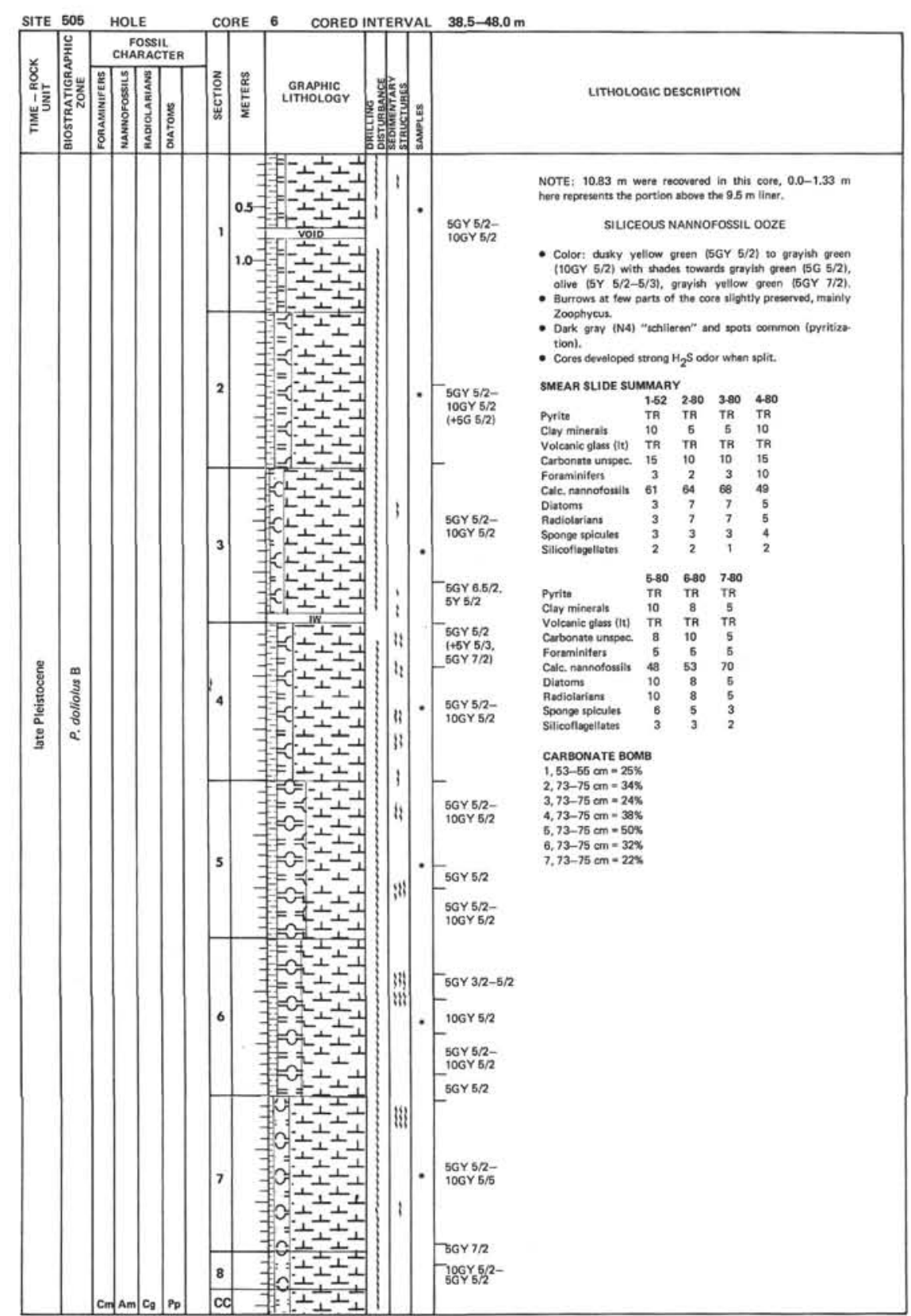




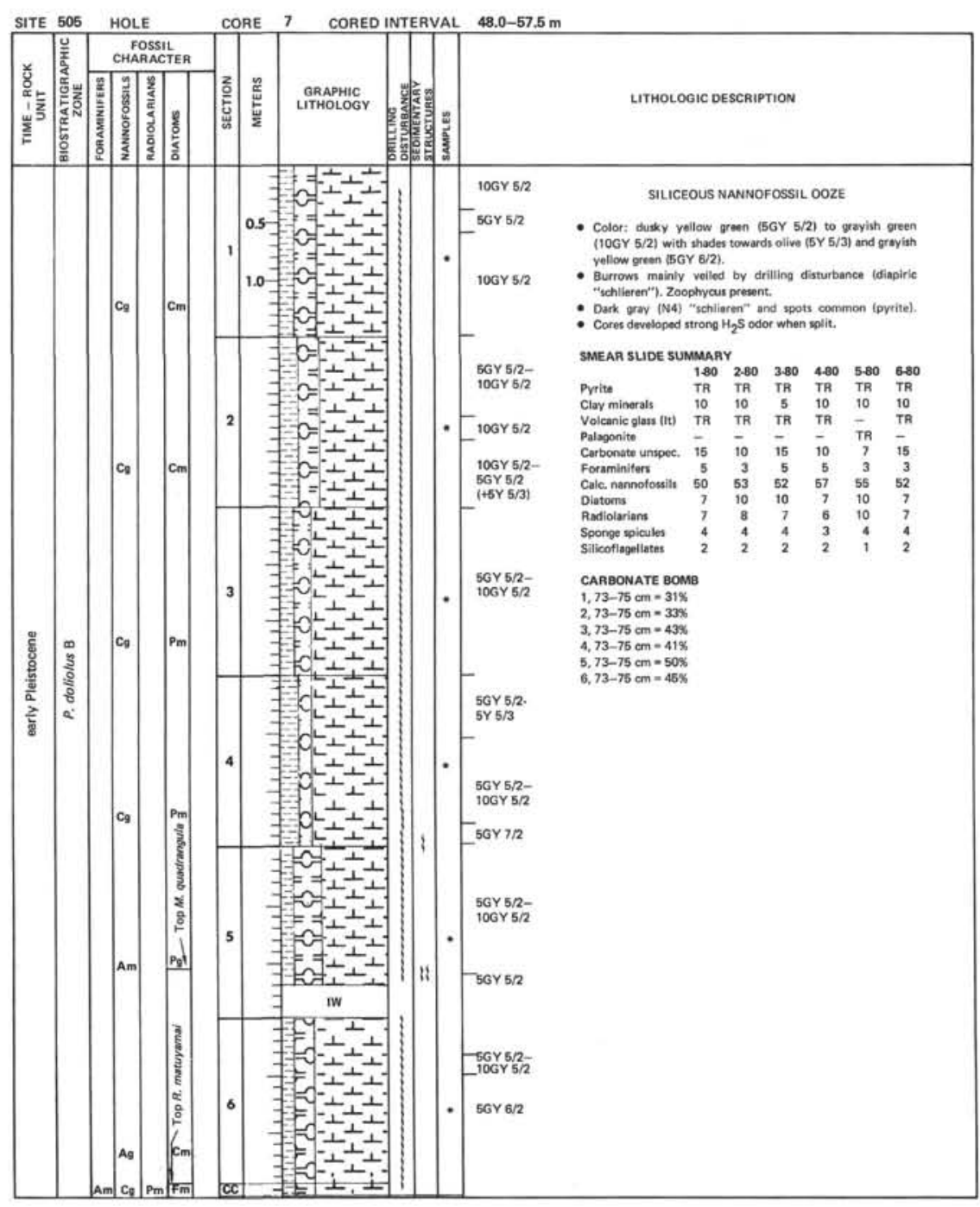

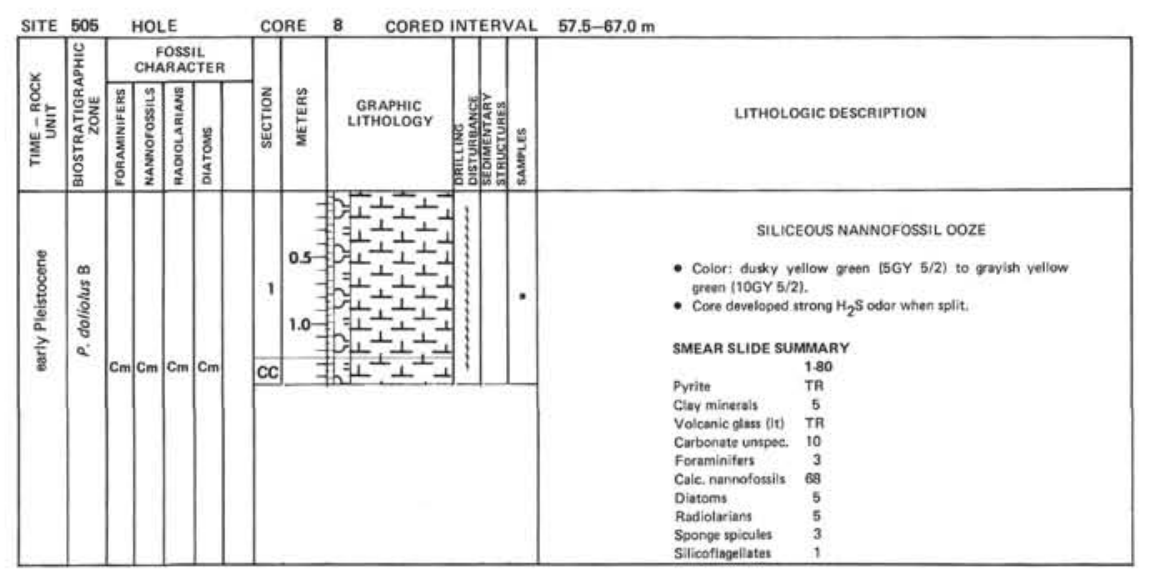

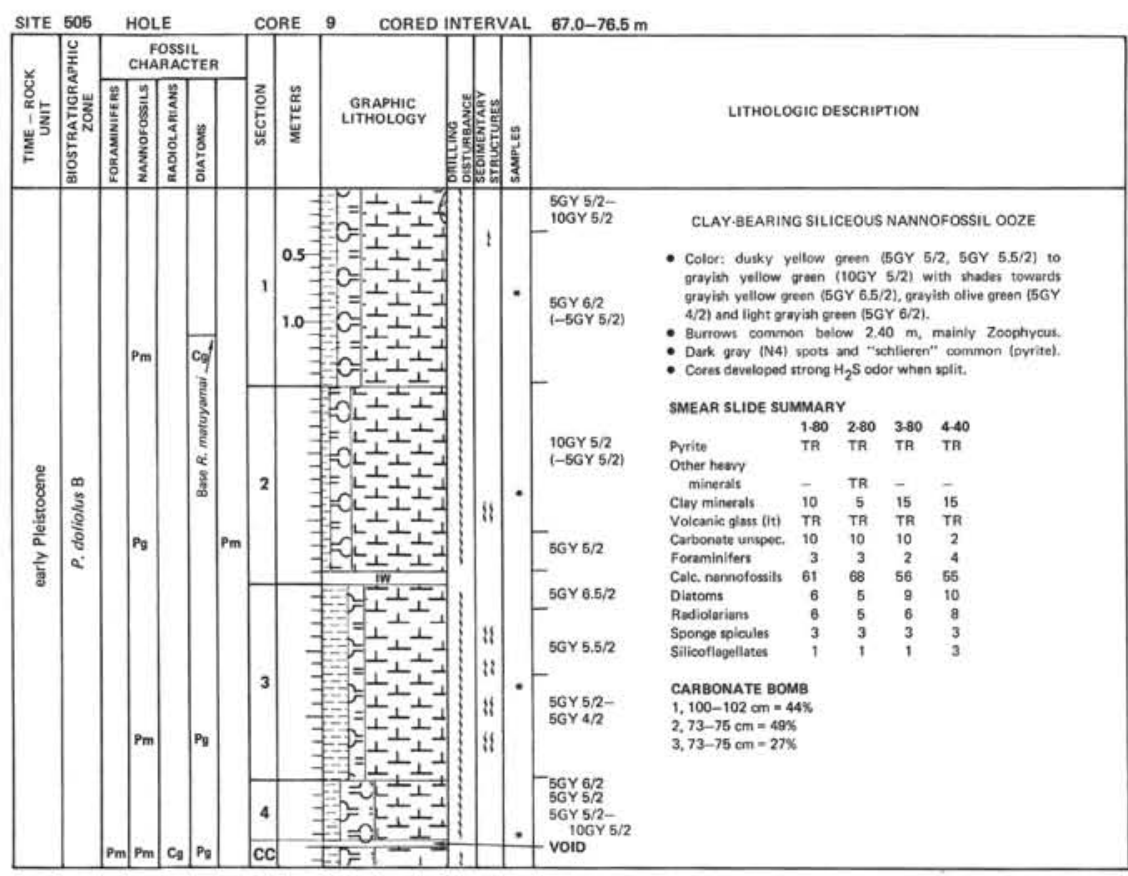



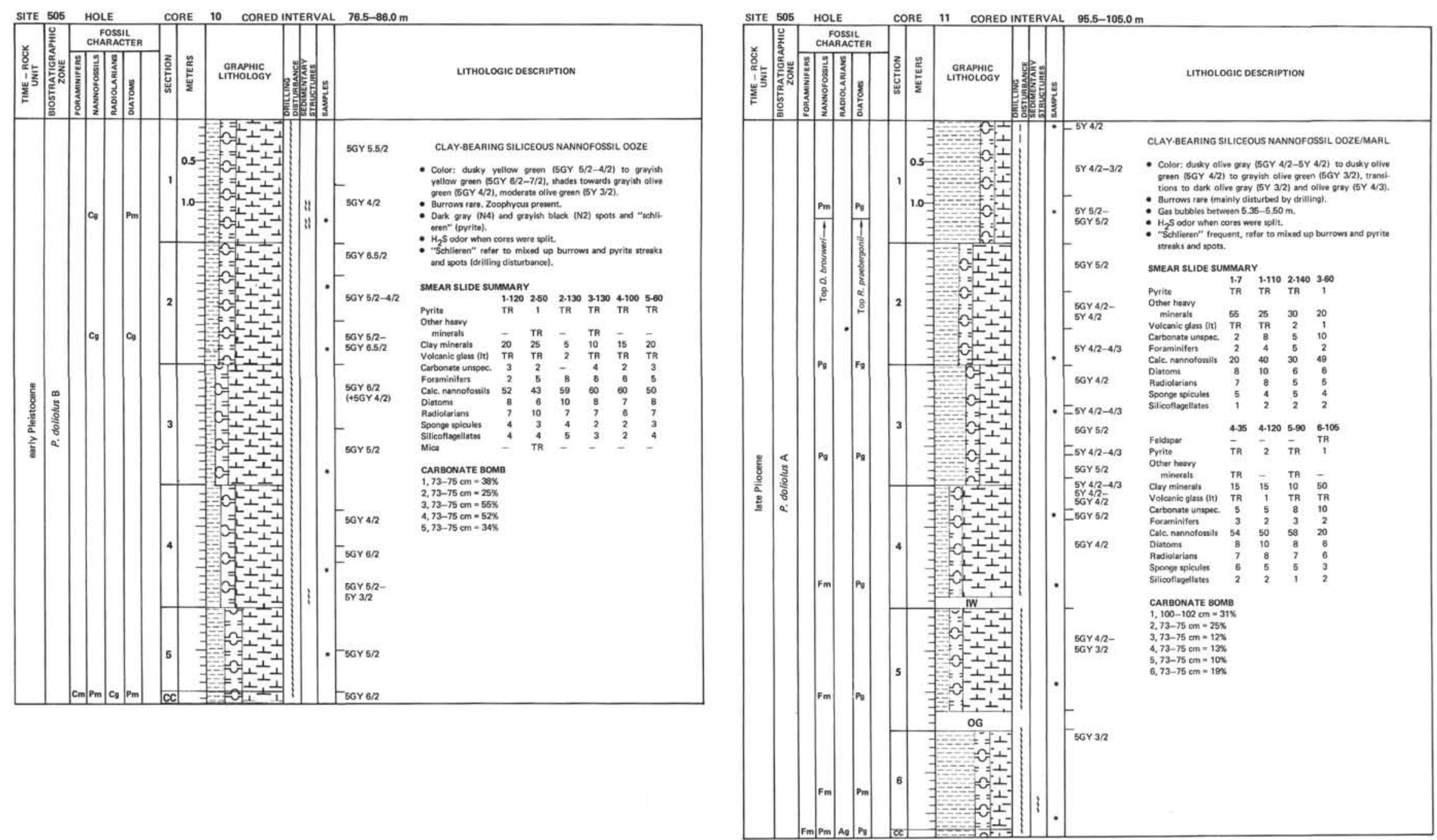


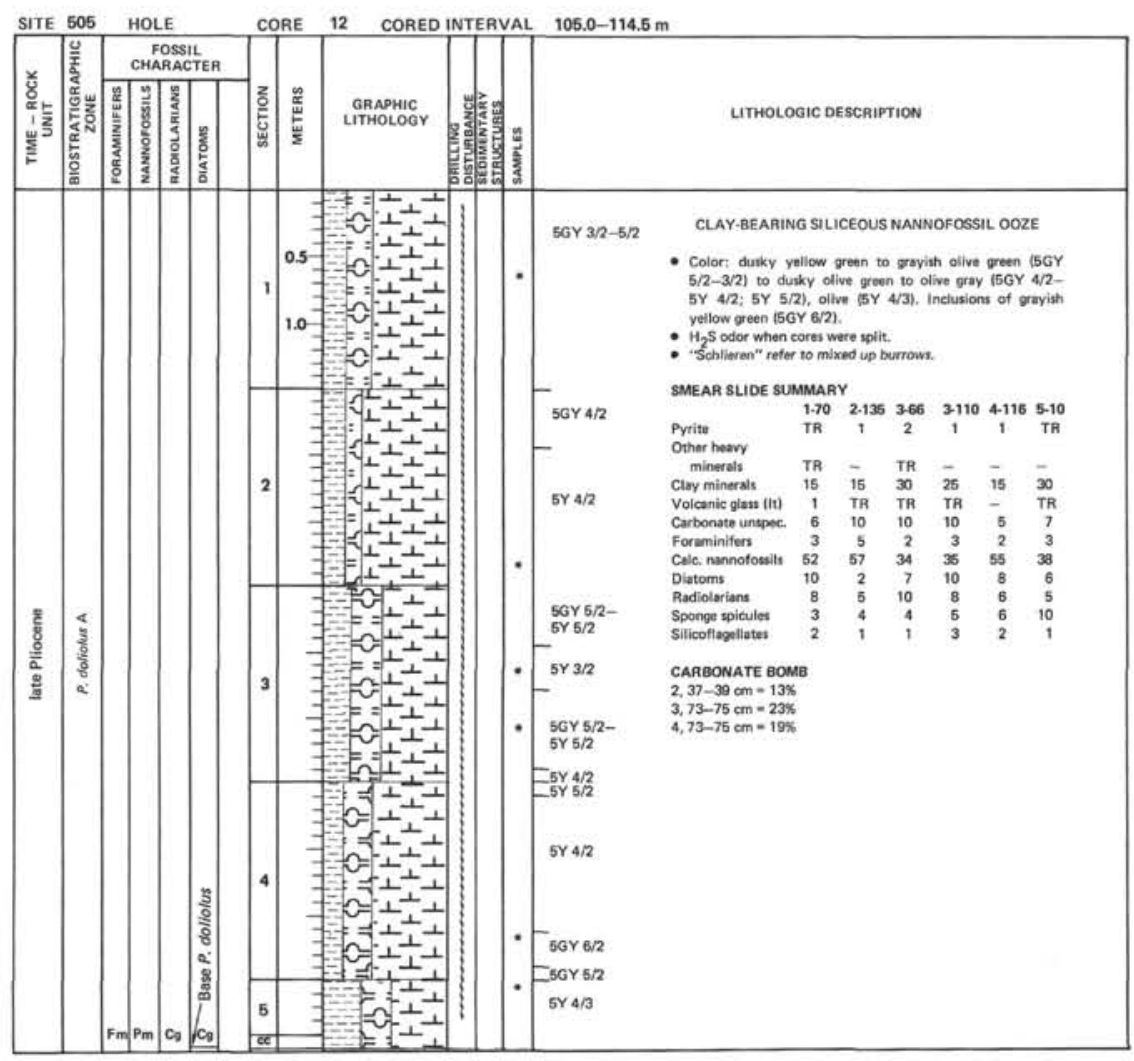

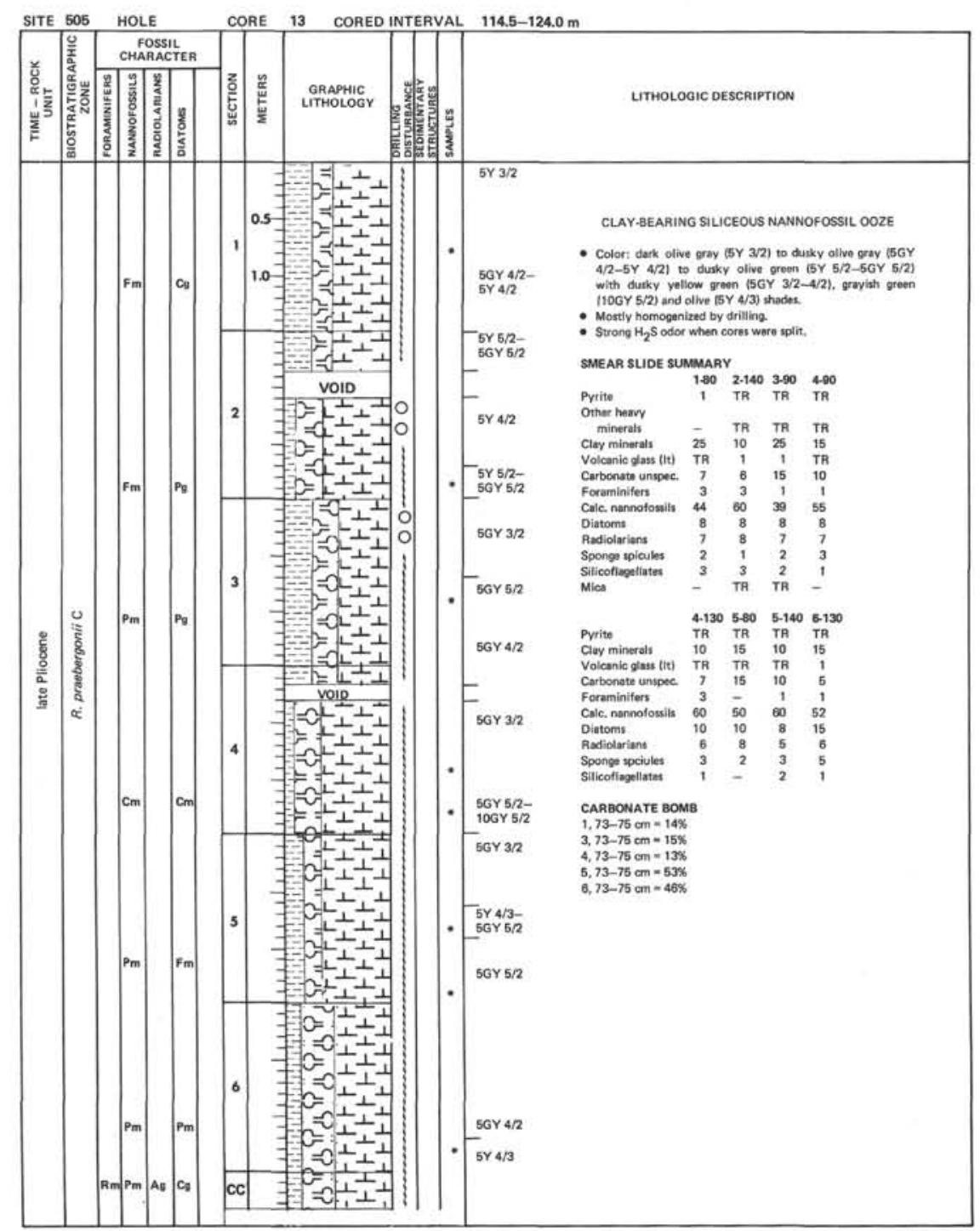



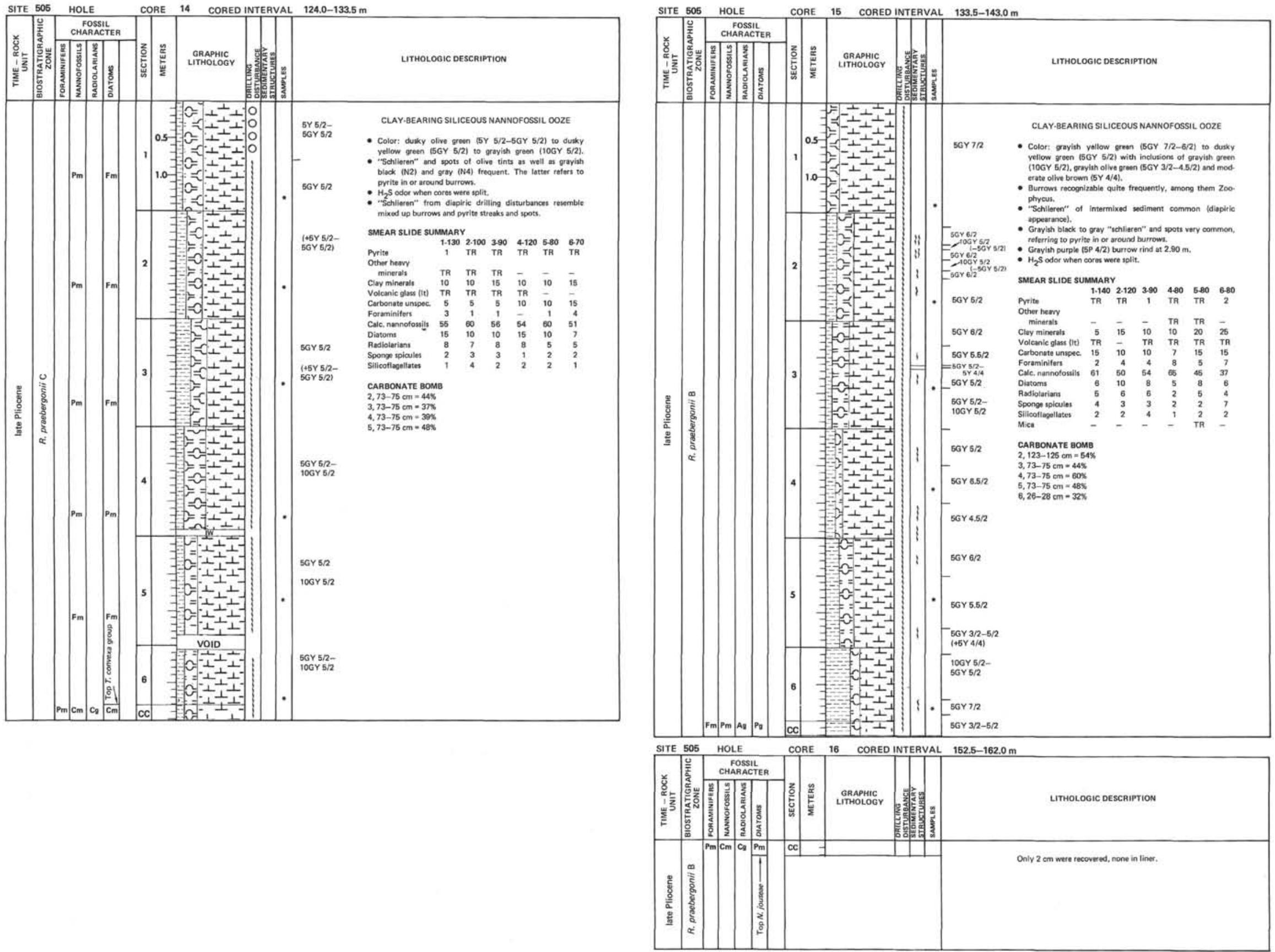

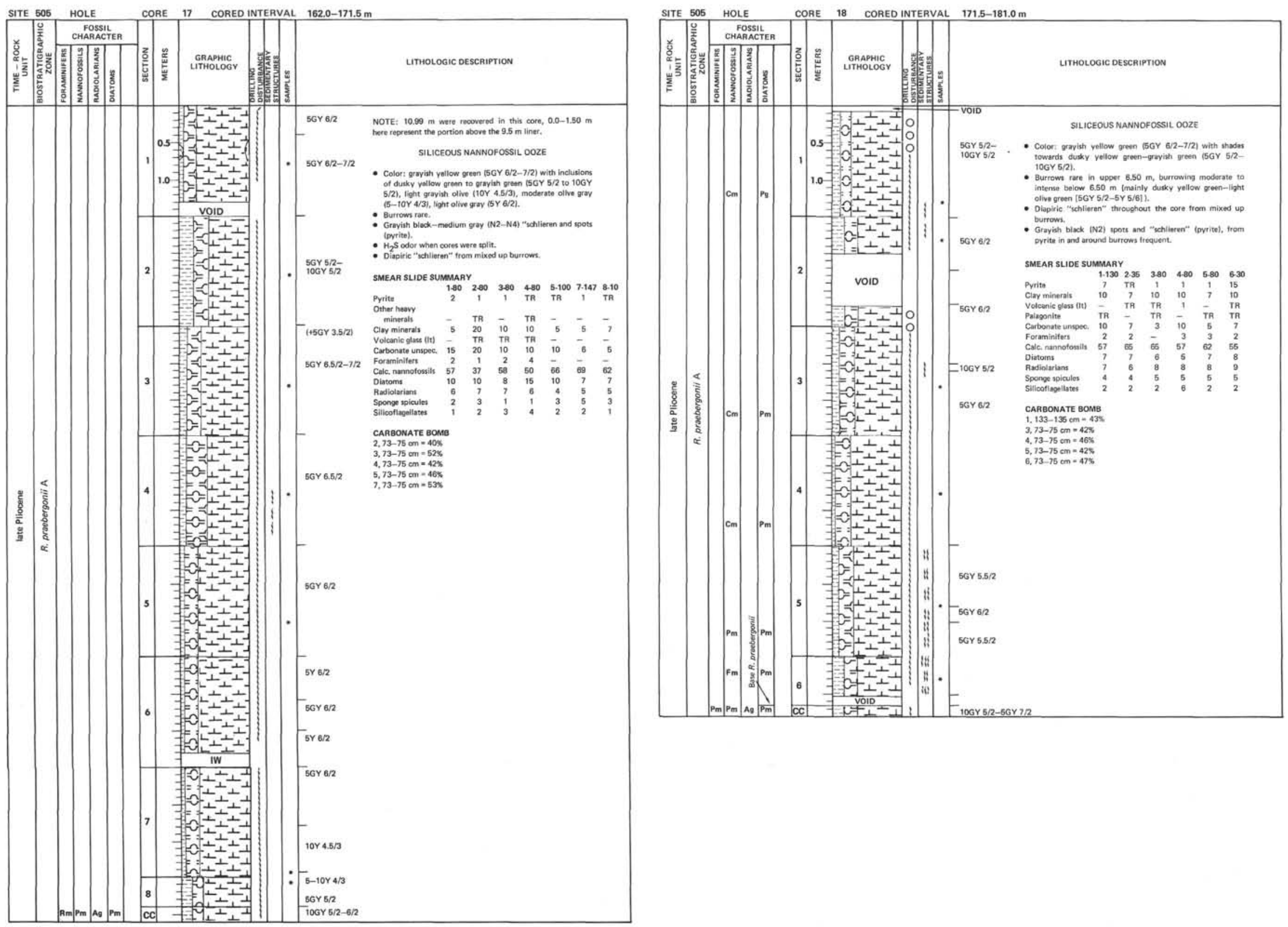

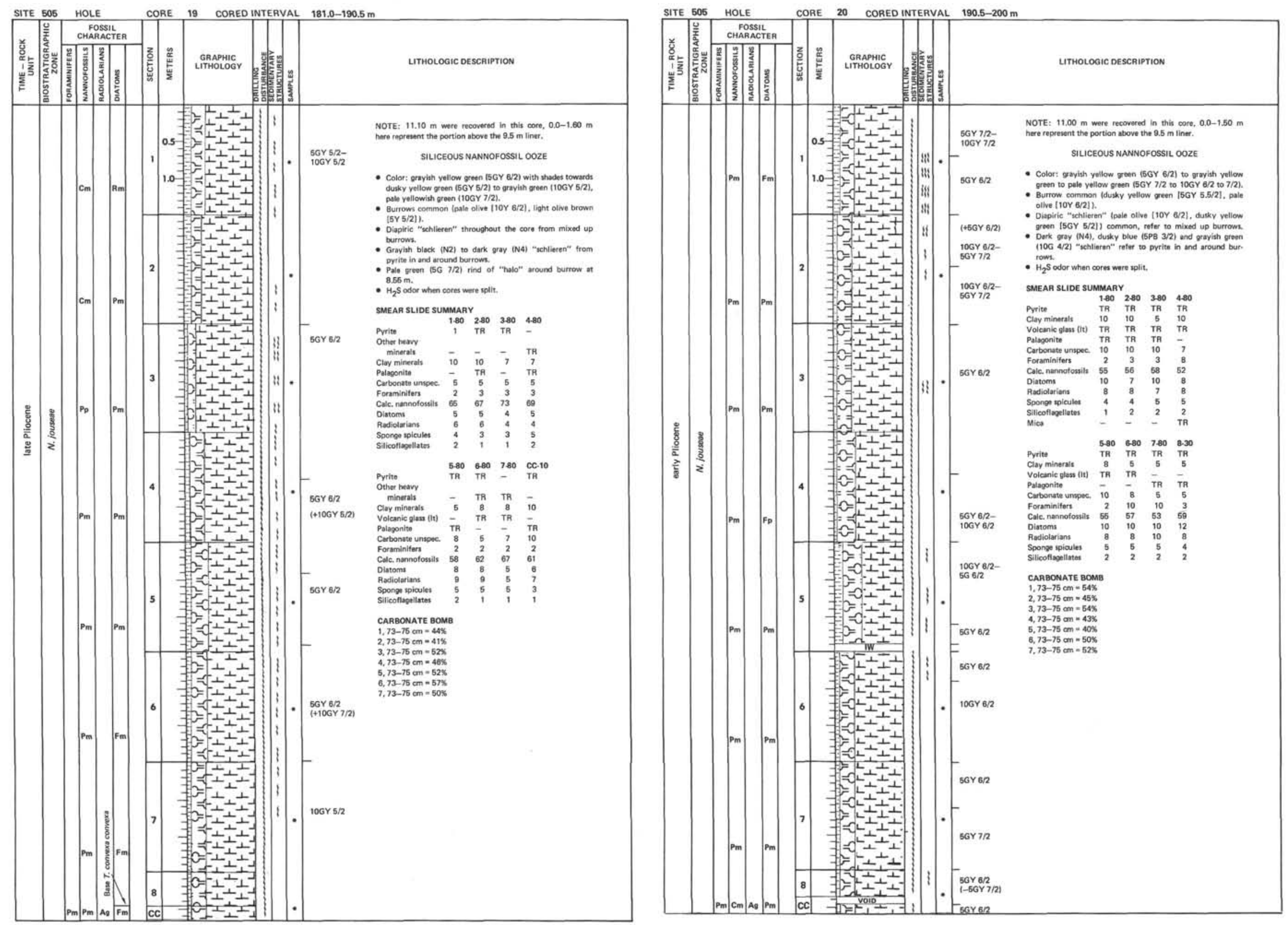


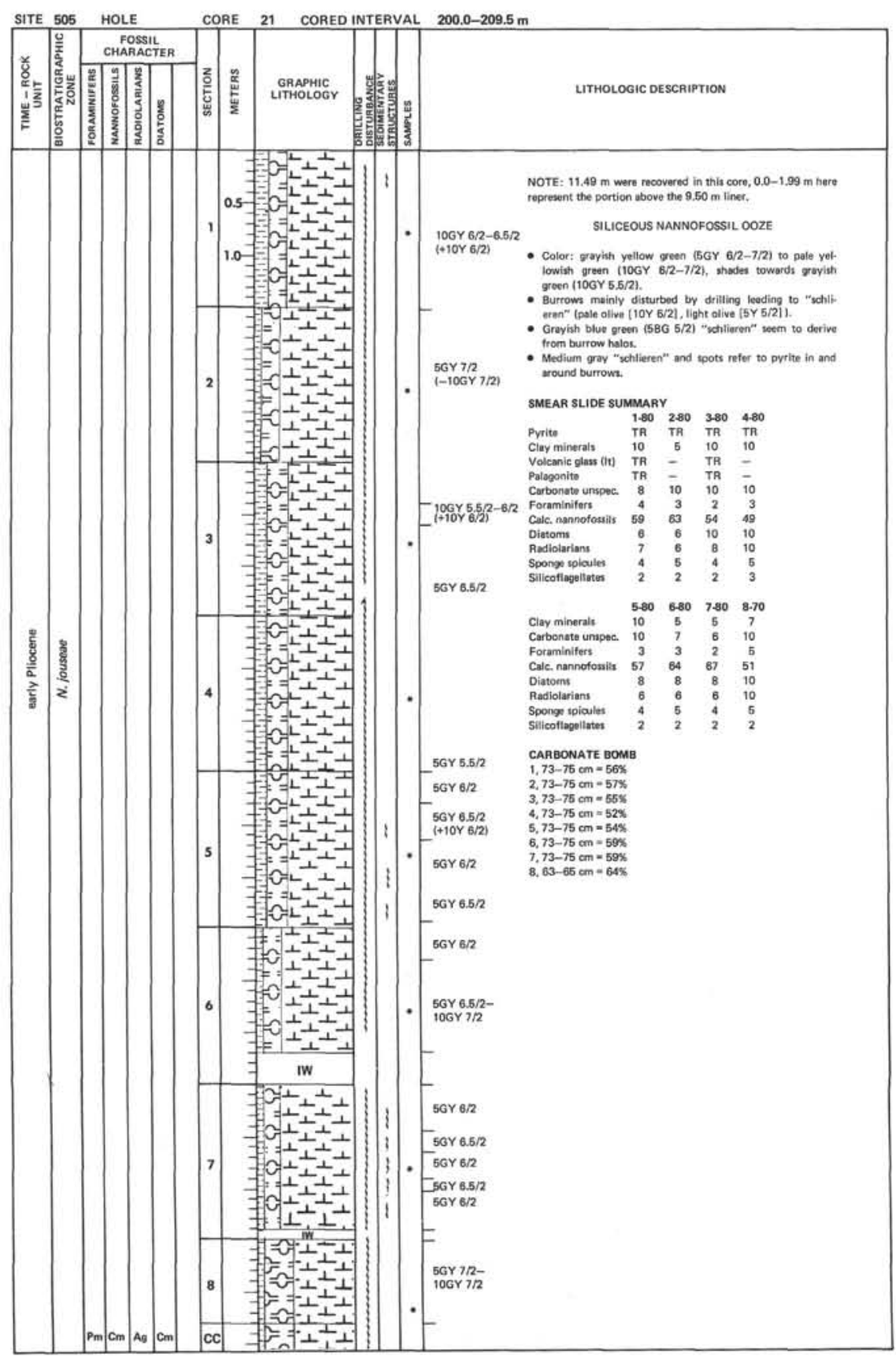

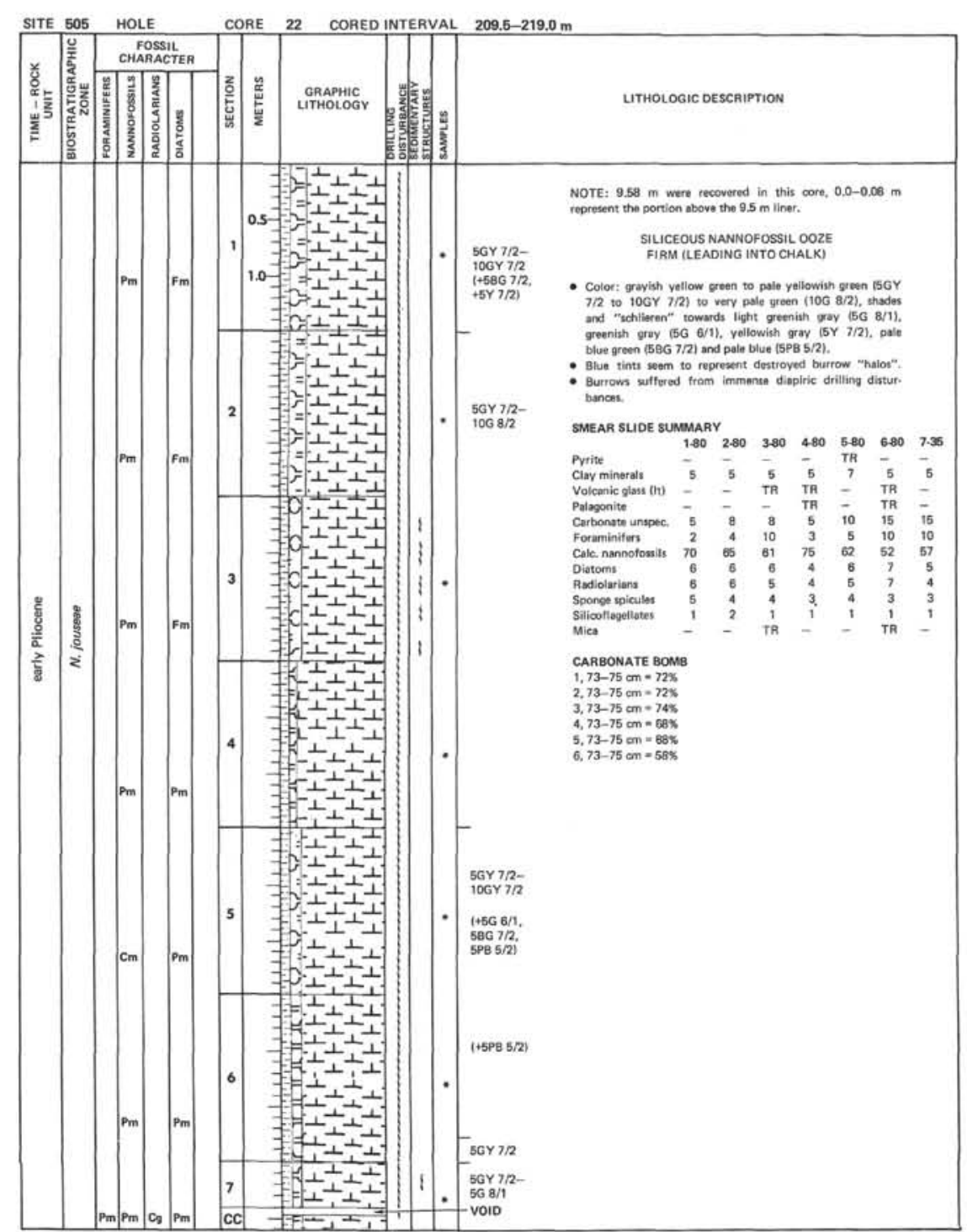


ఫू

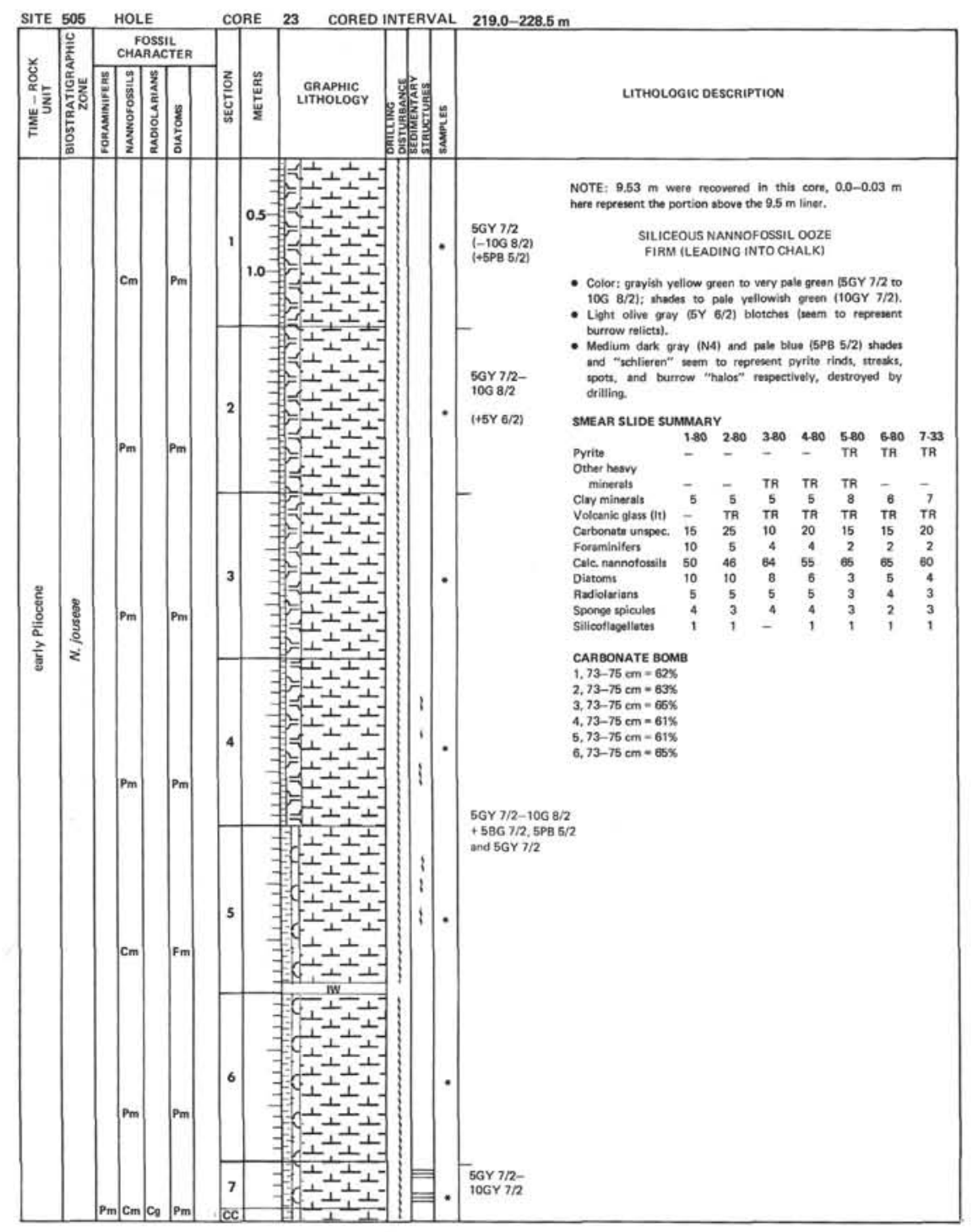

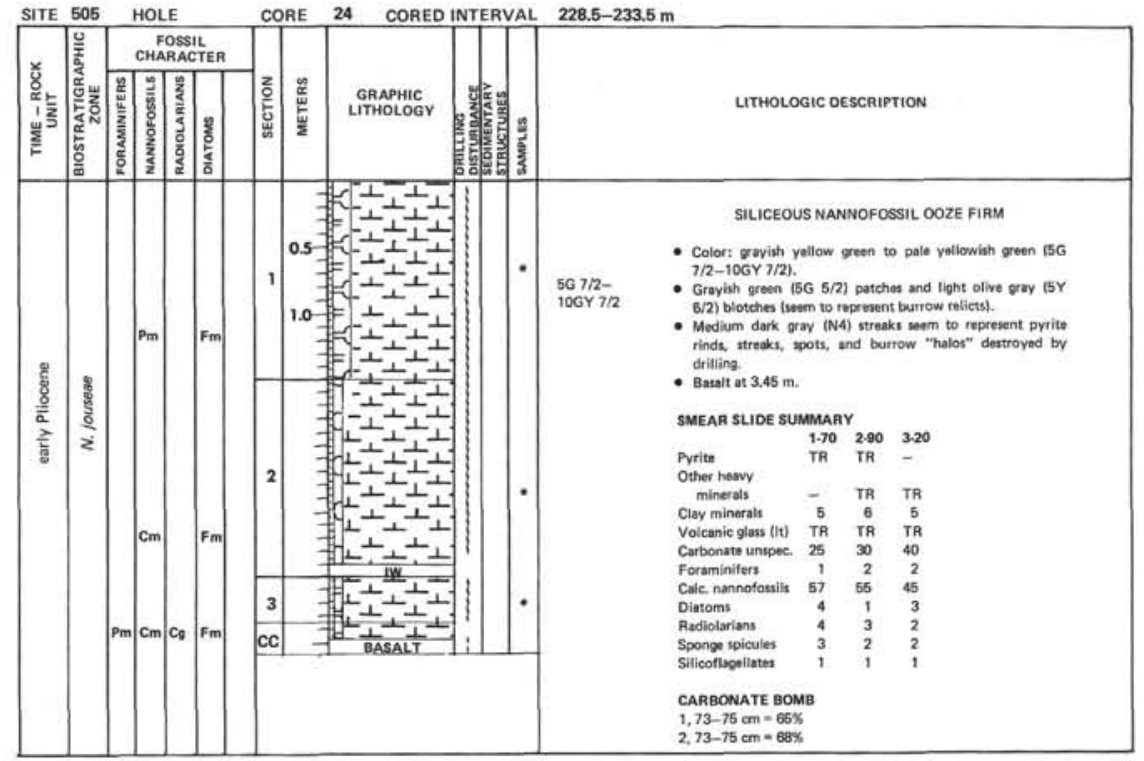




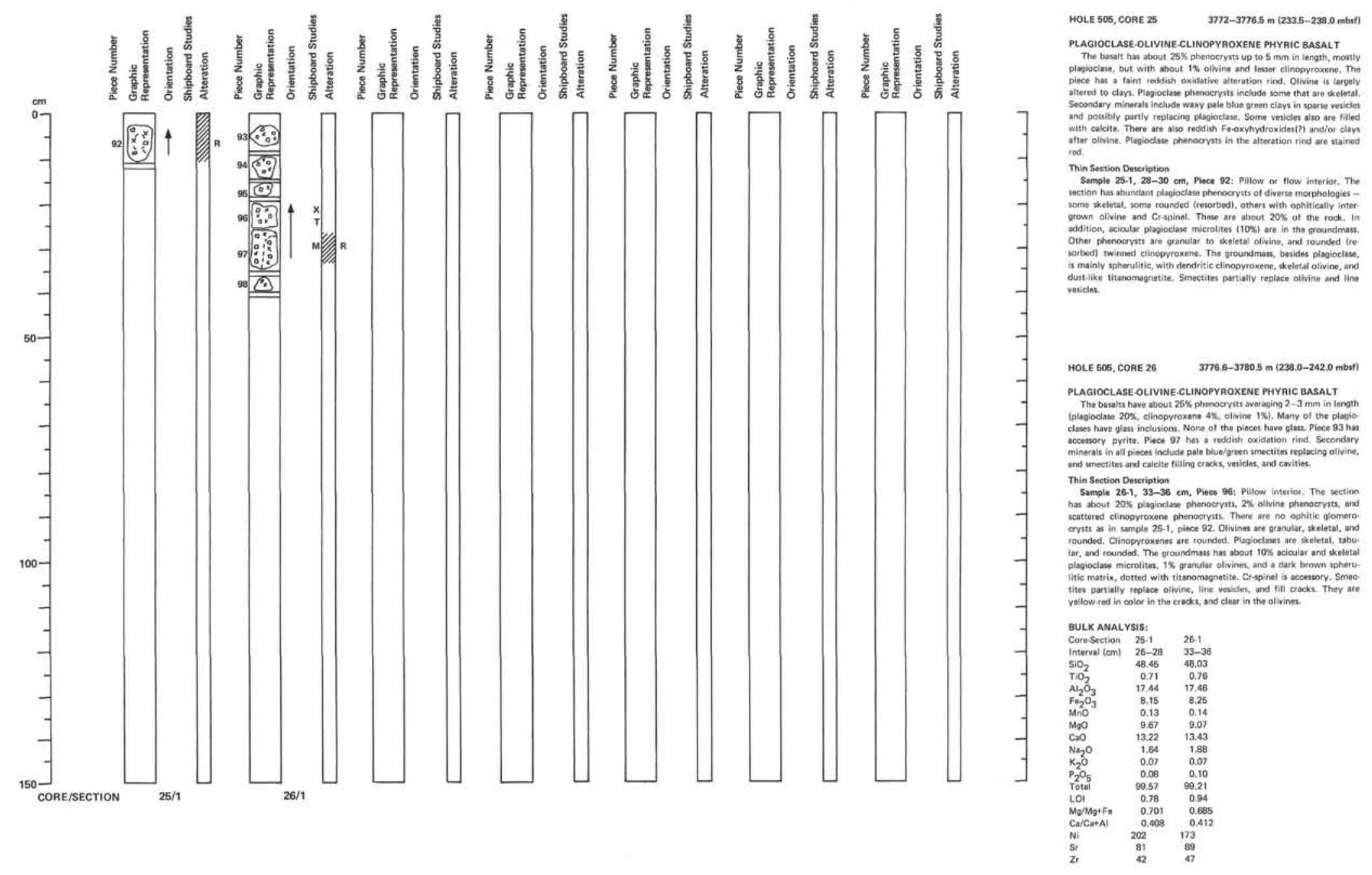




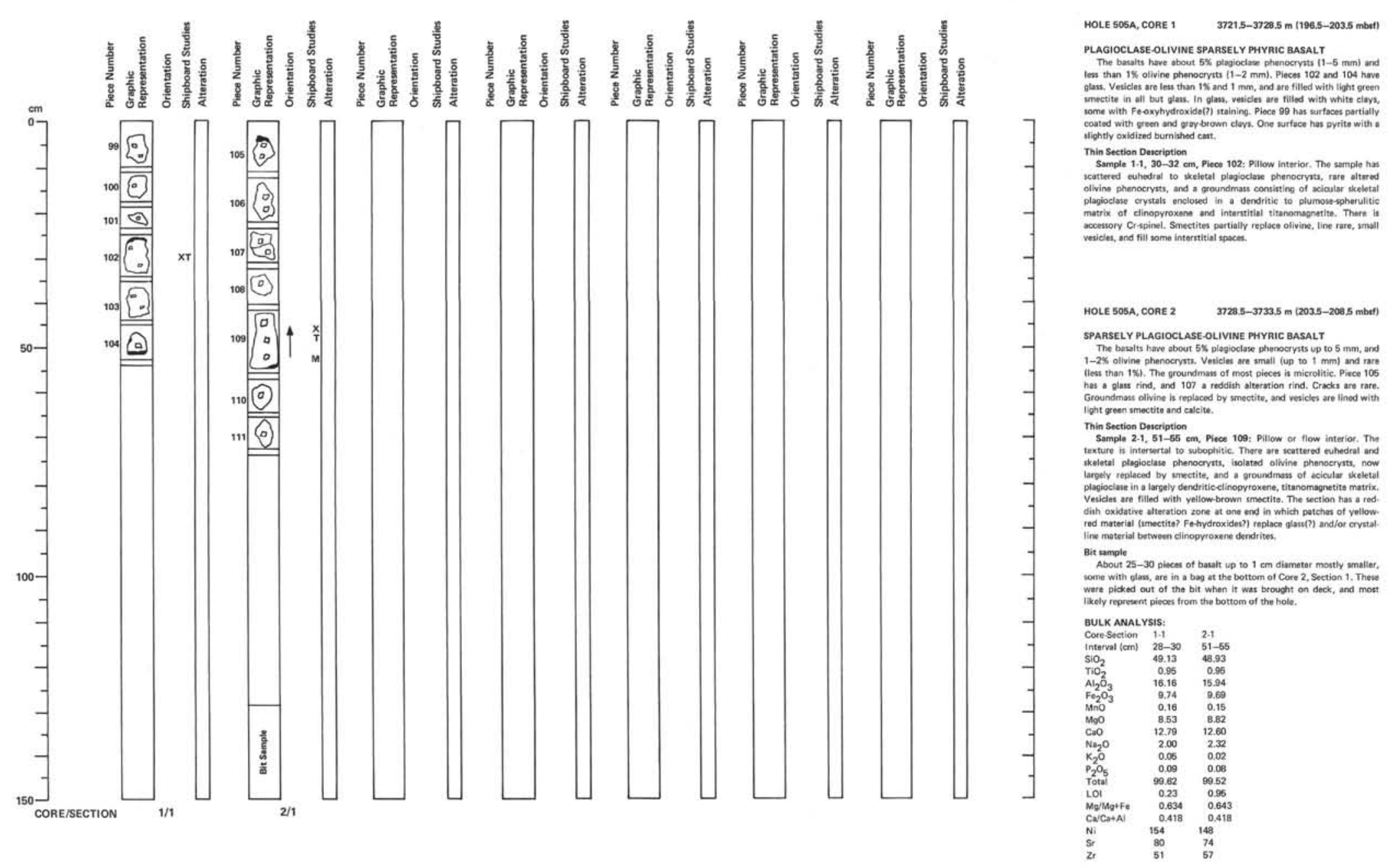




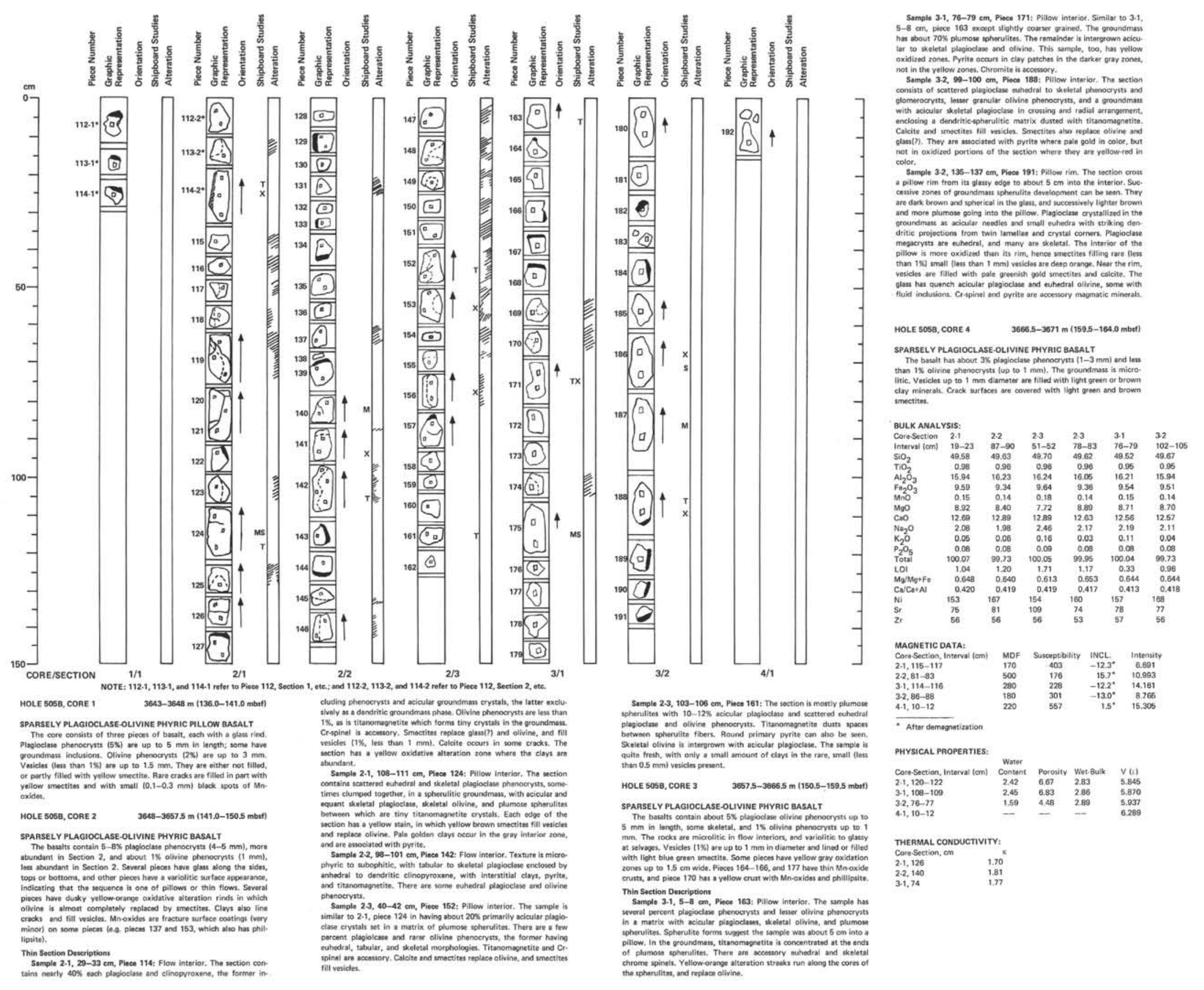




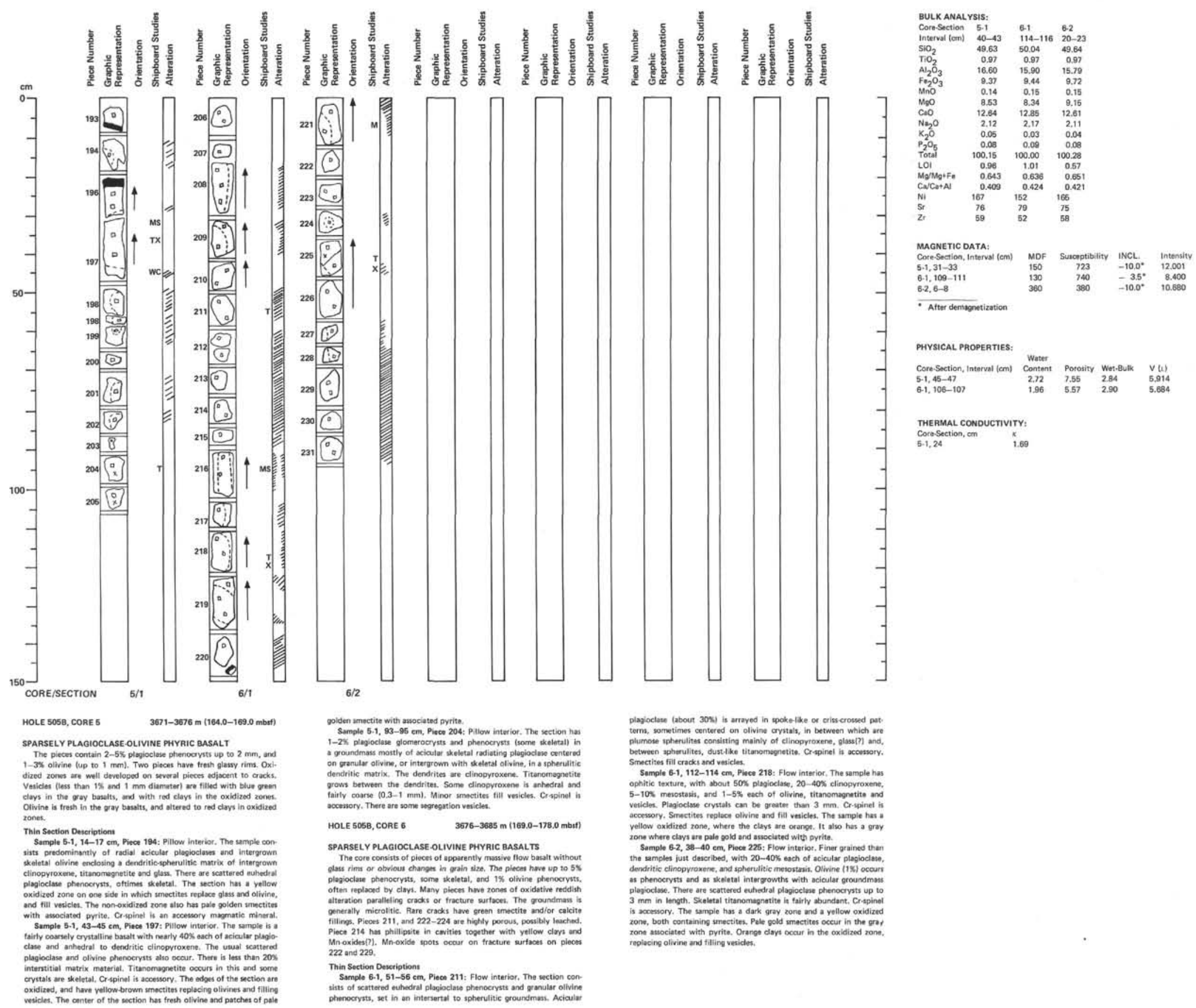




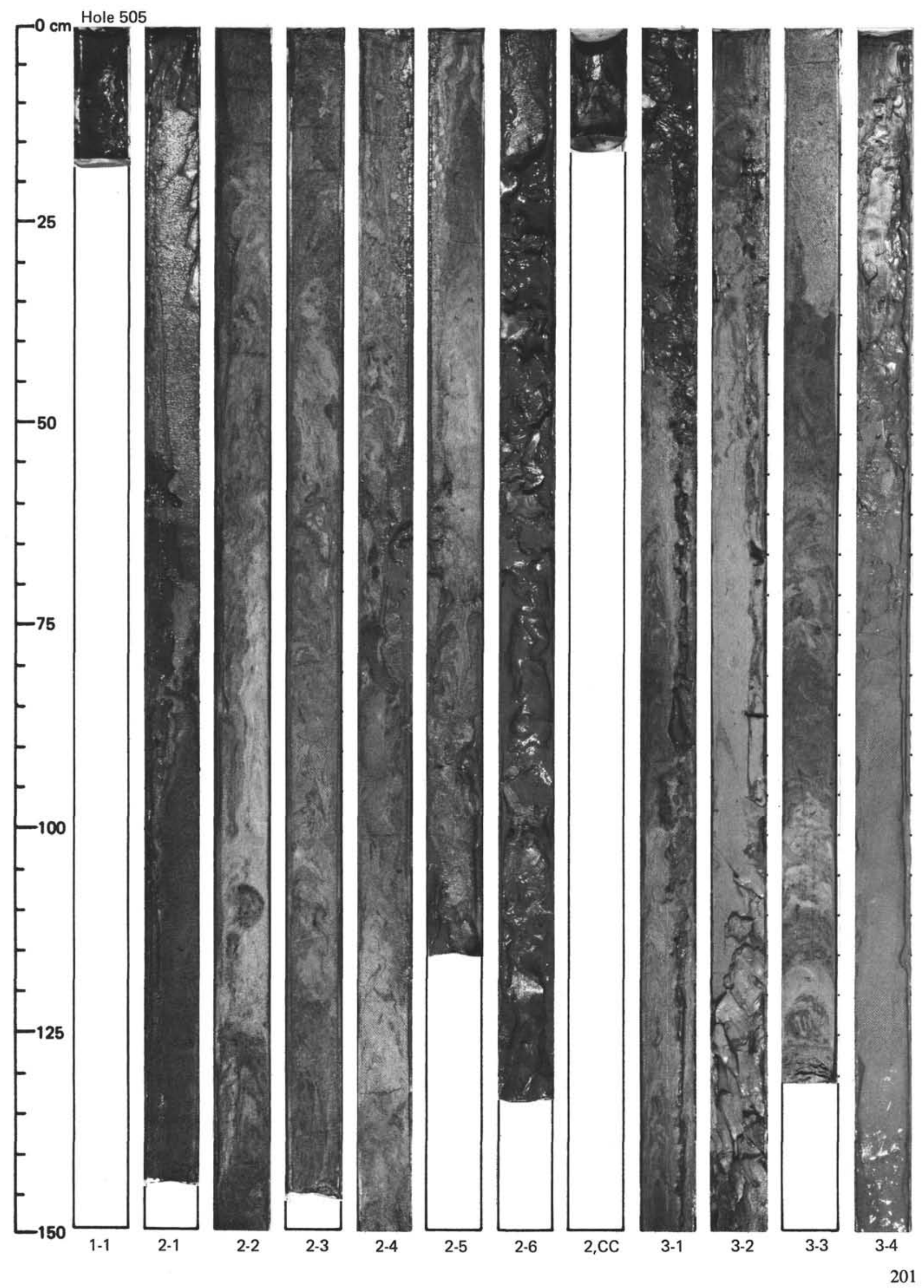




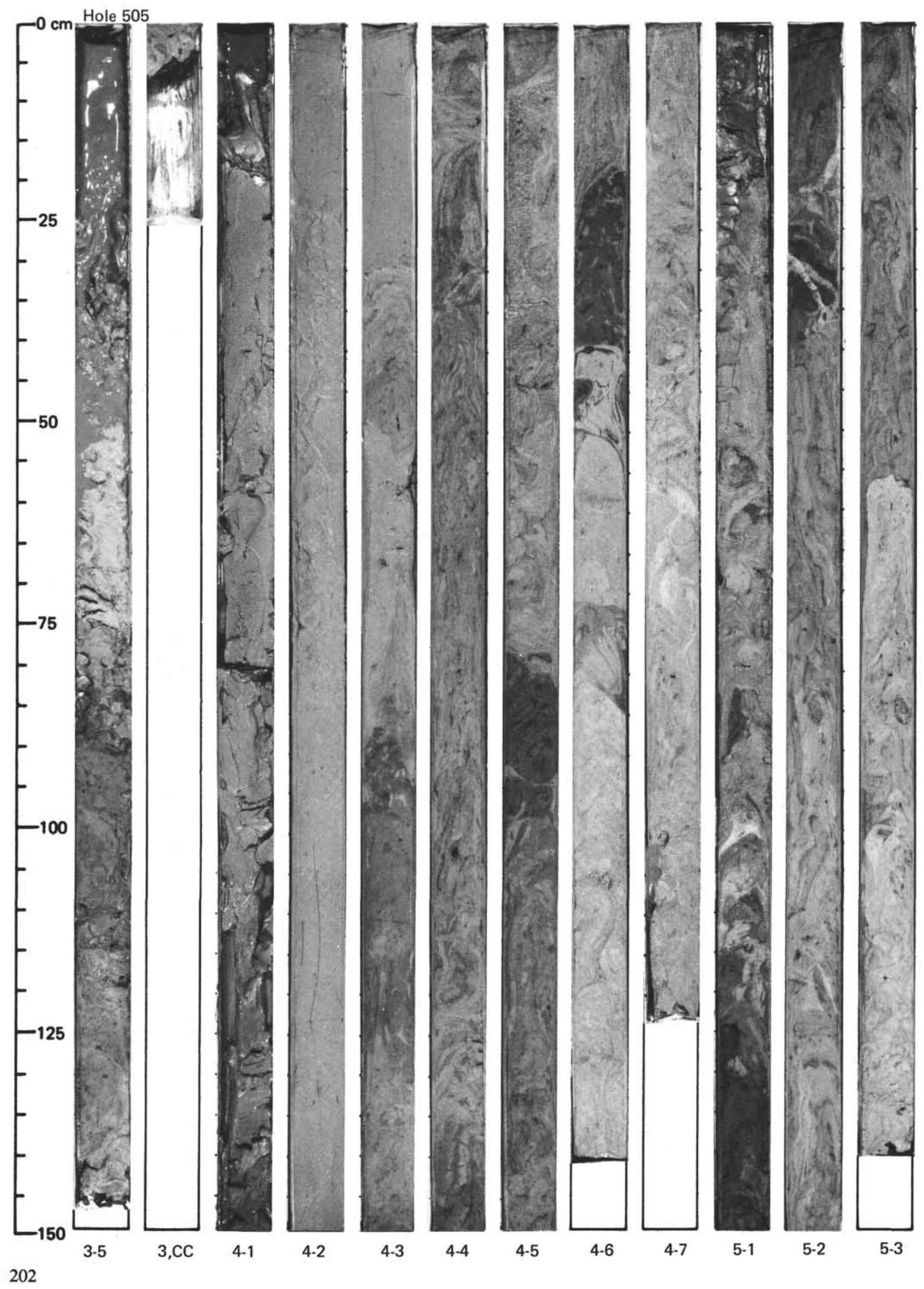




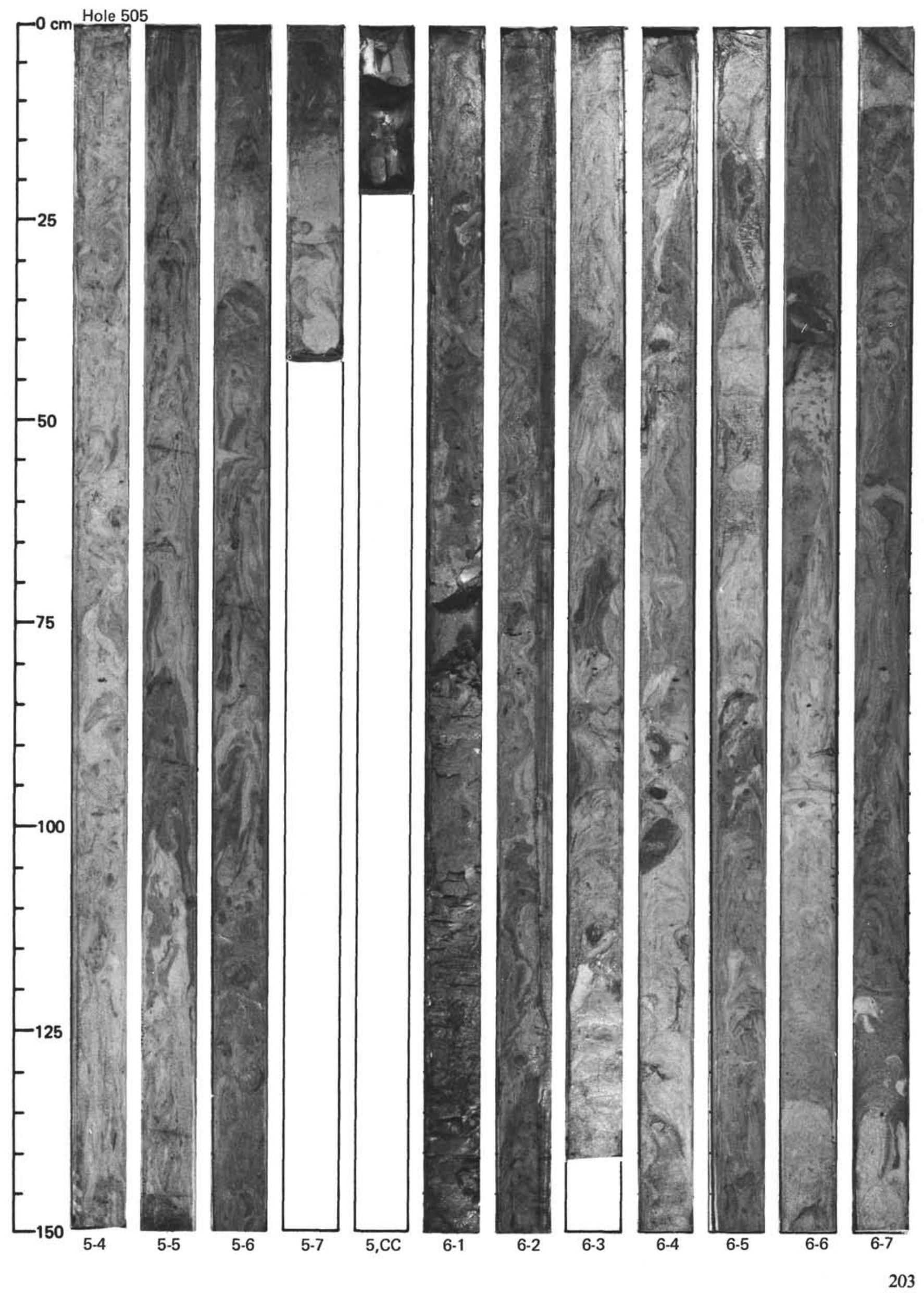




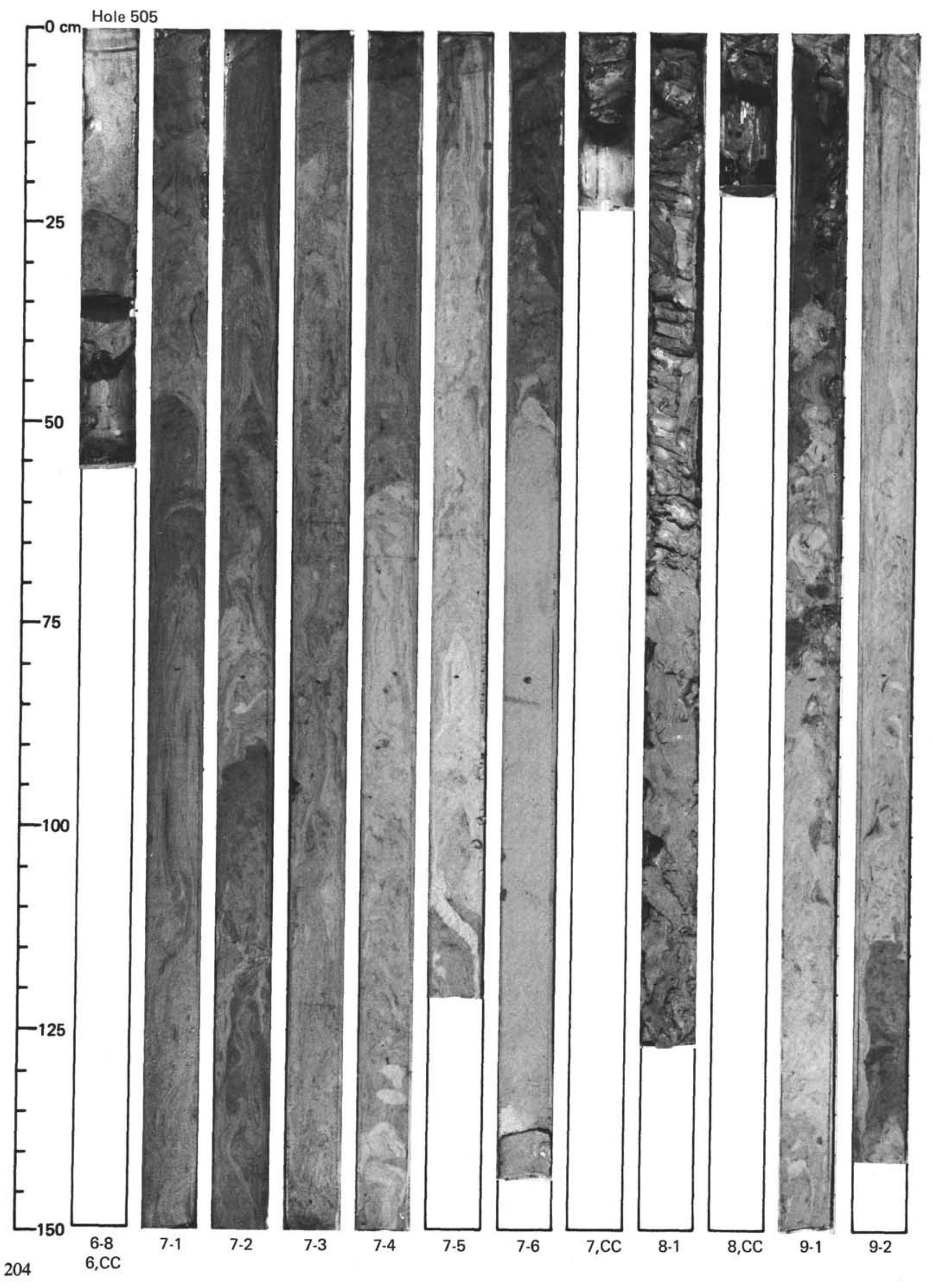




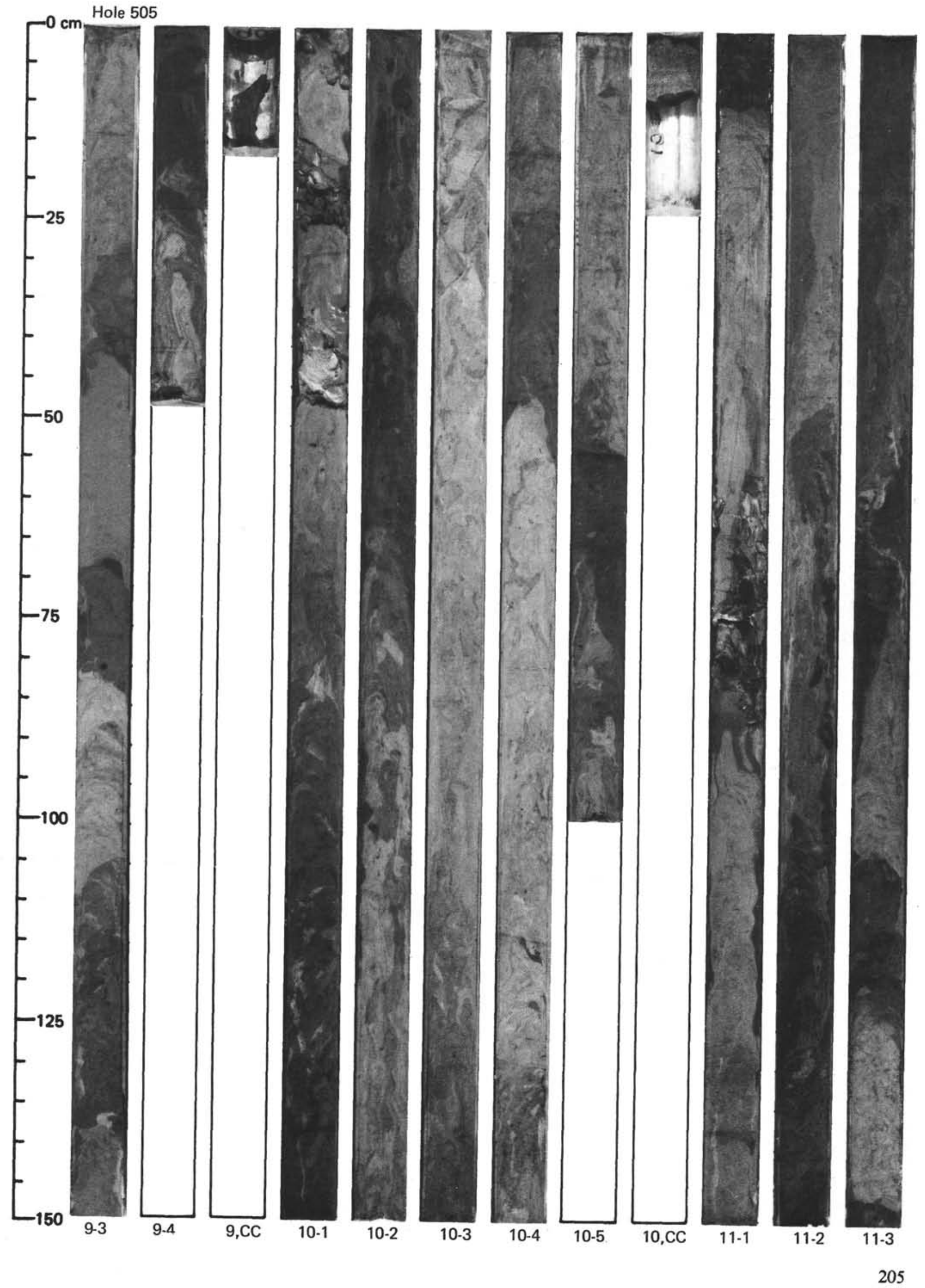




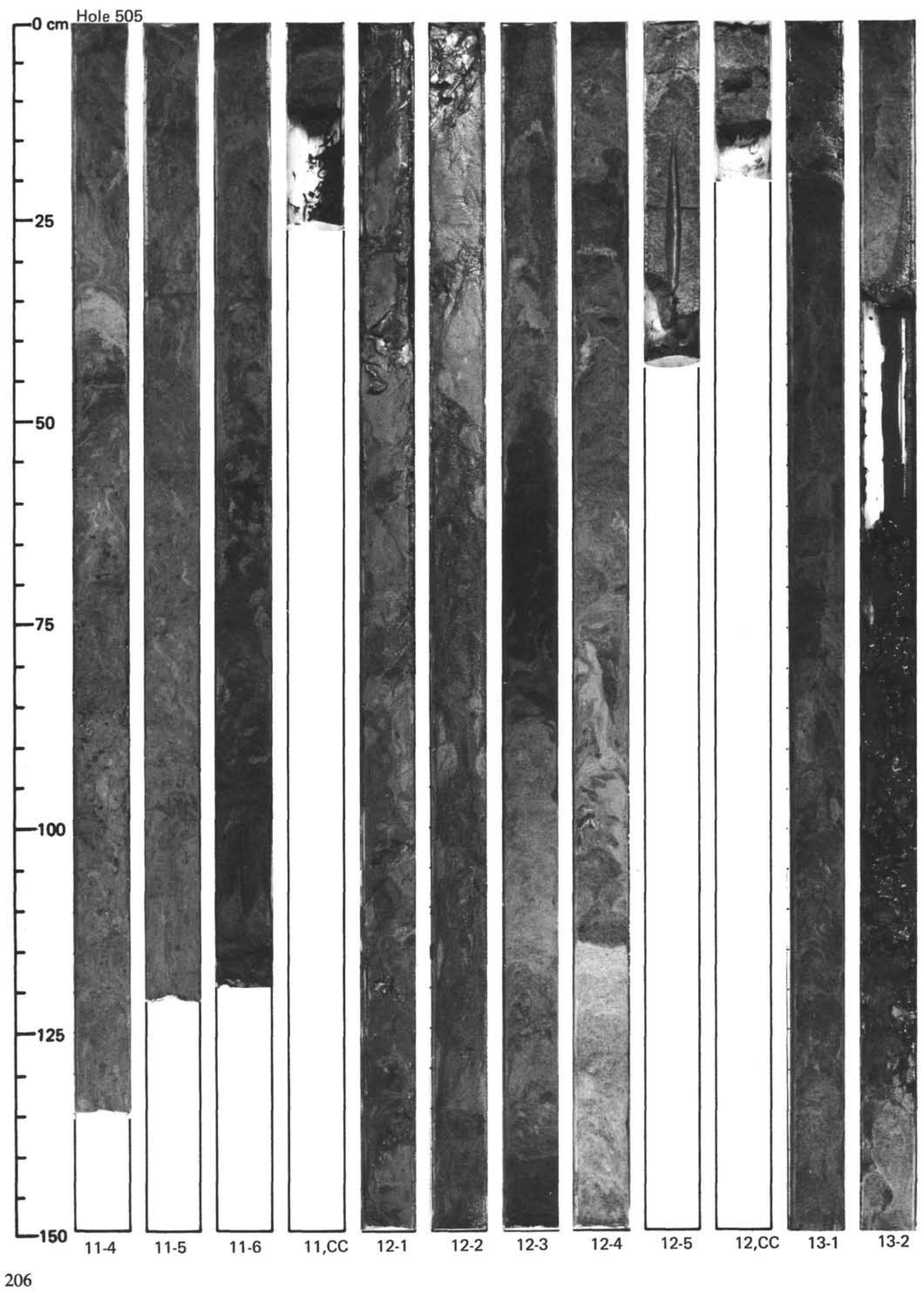




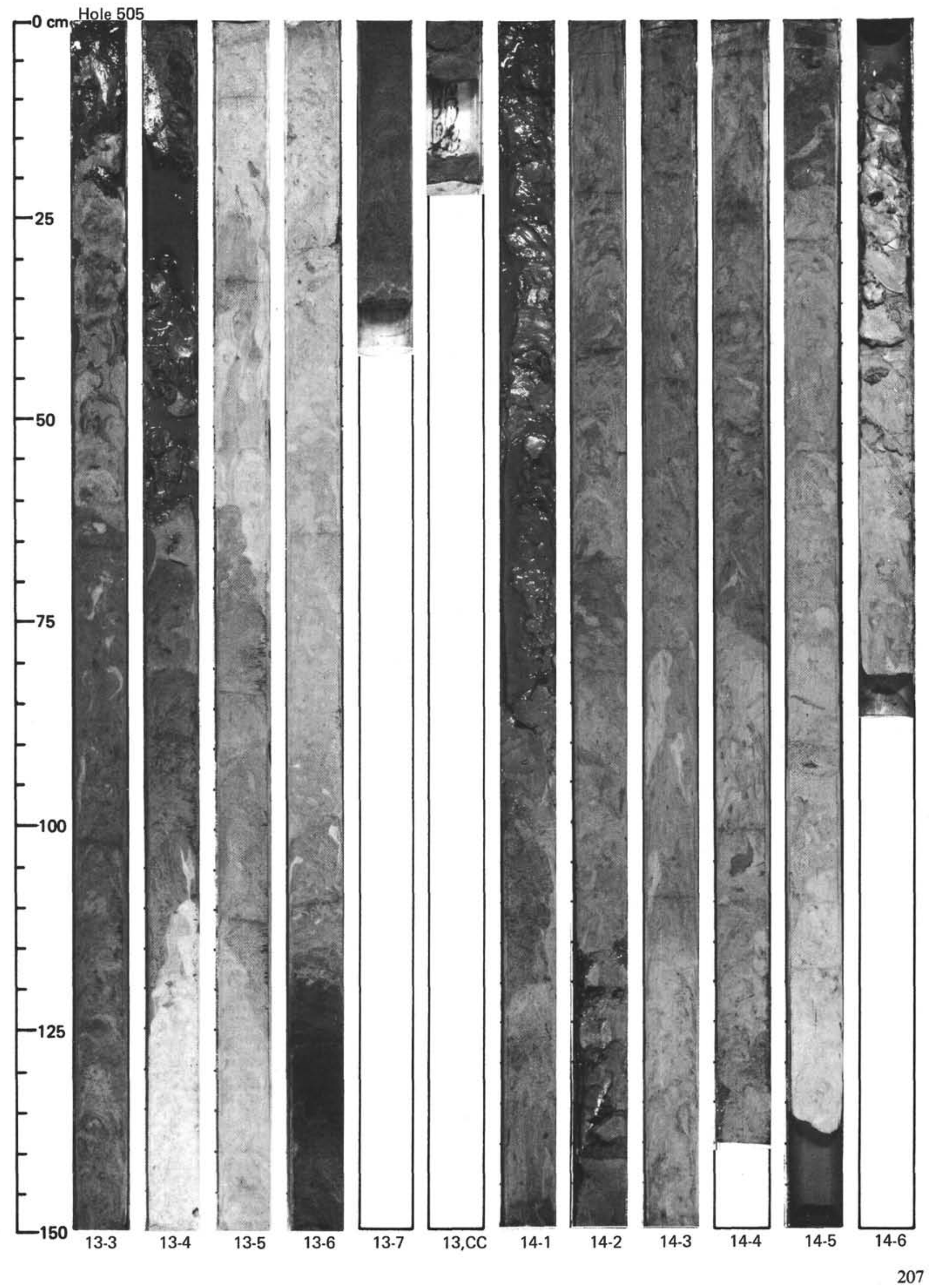




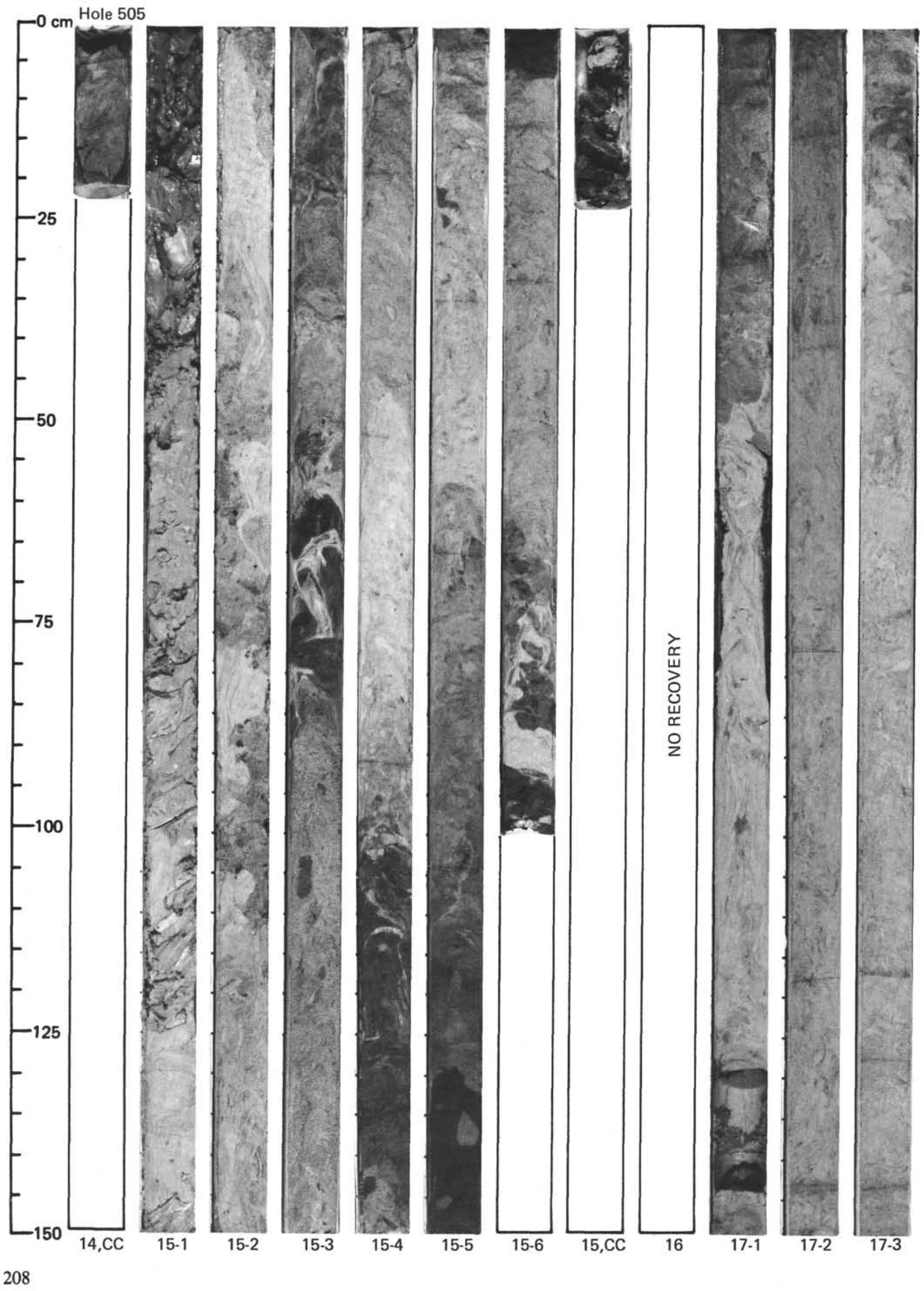



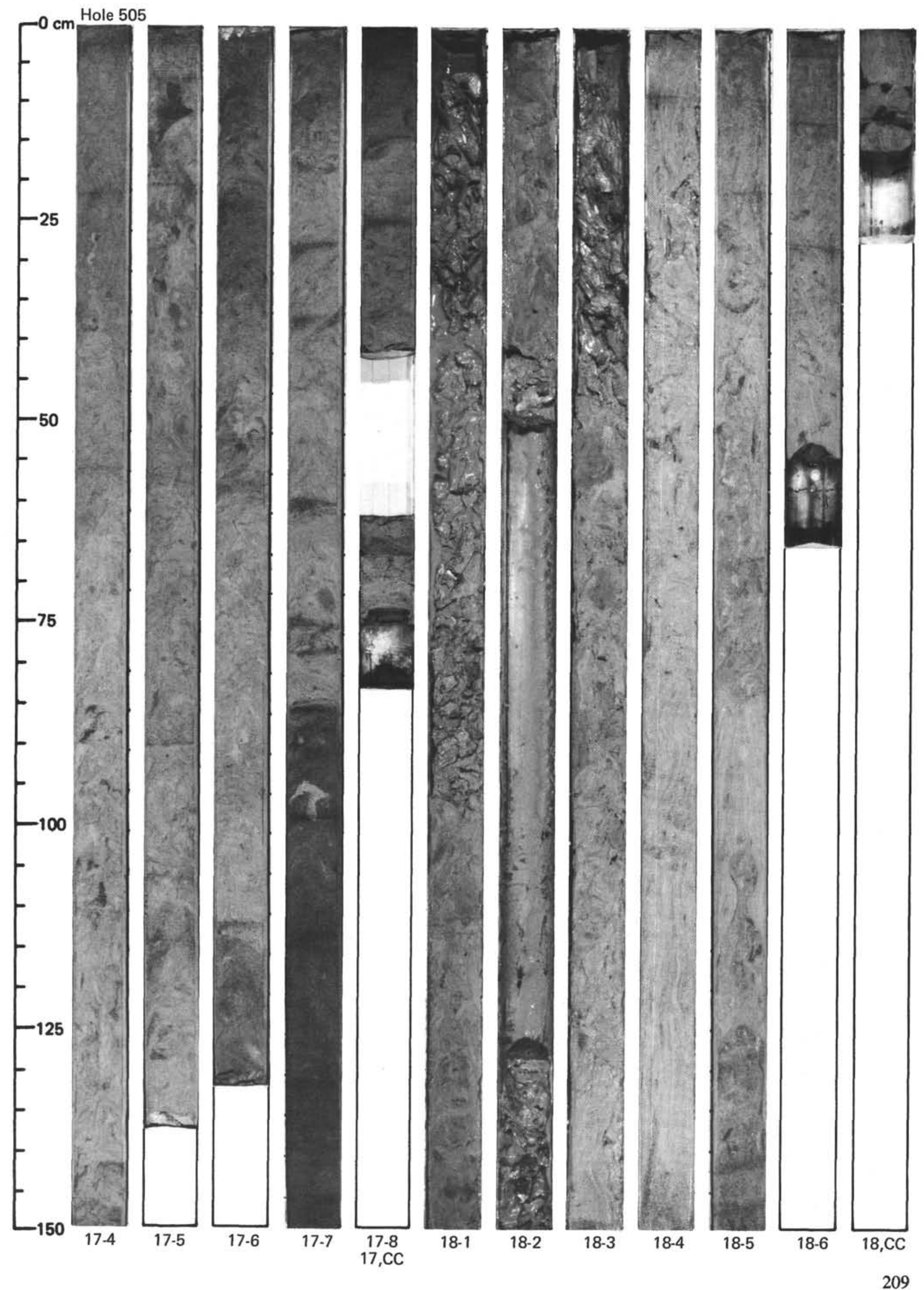


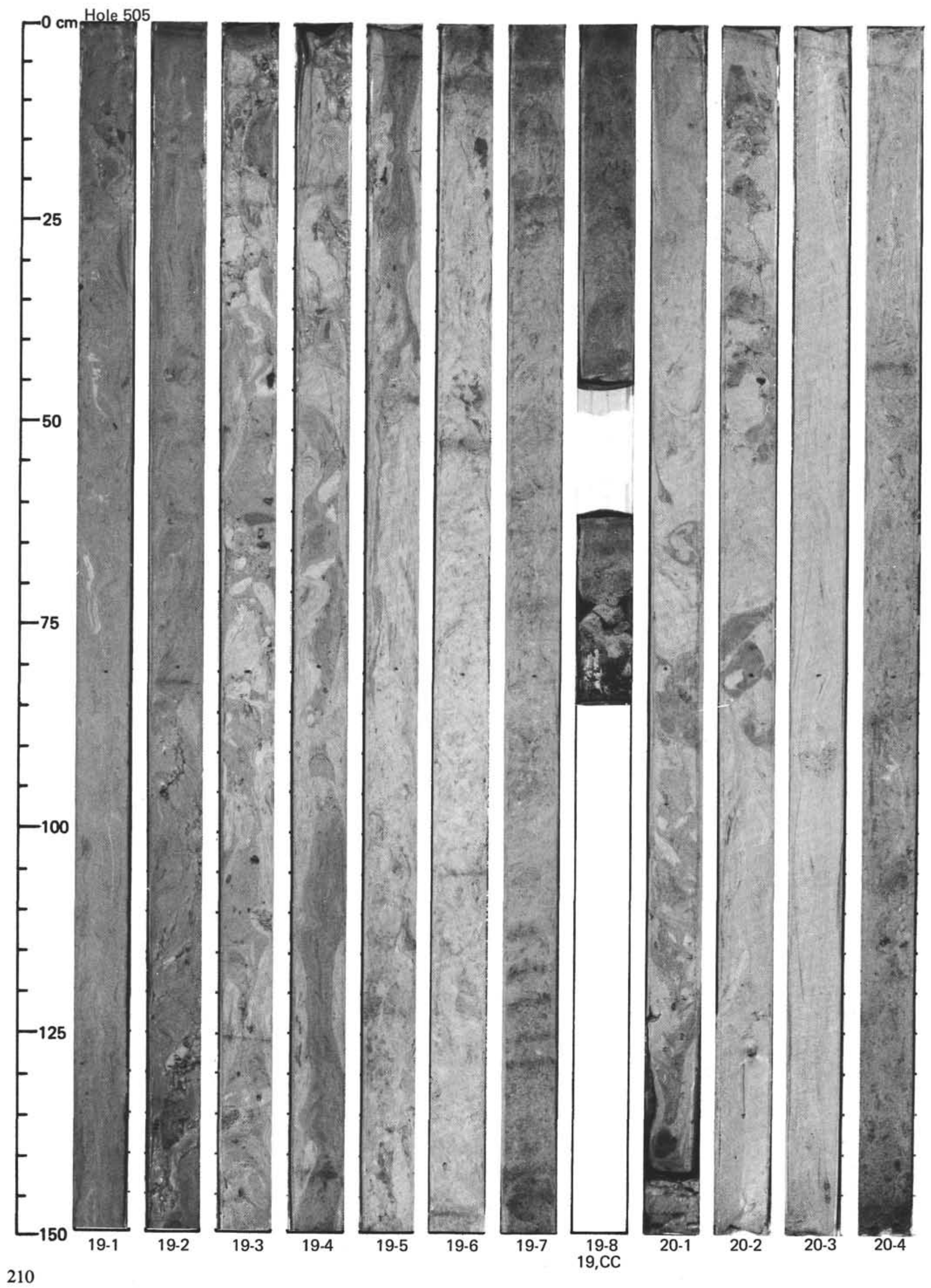




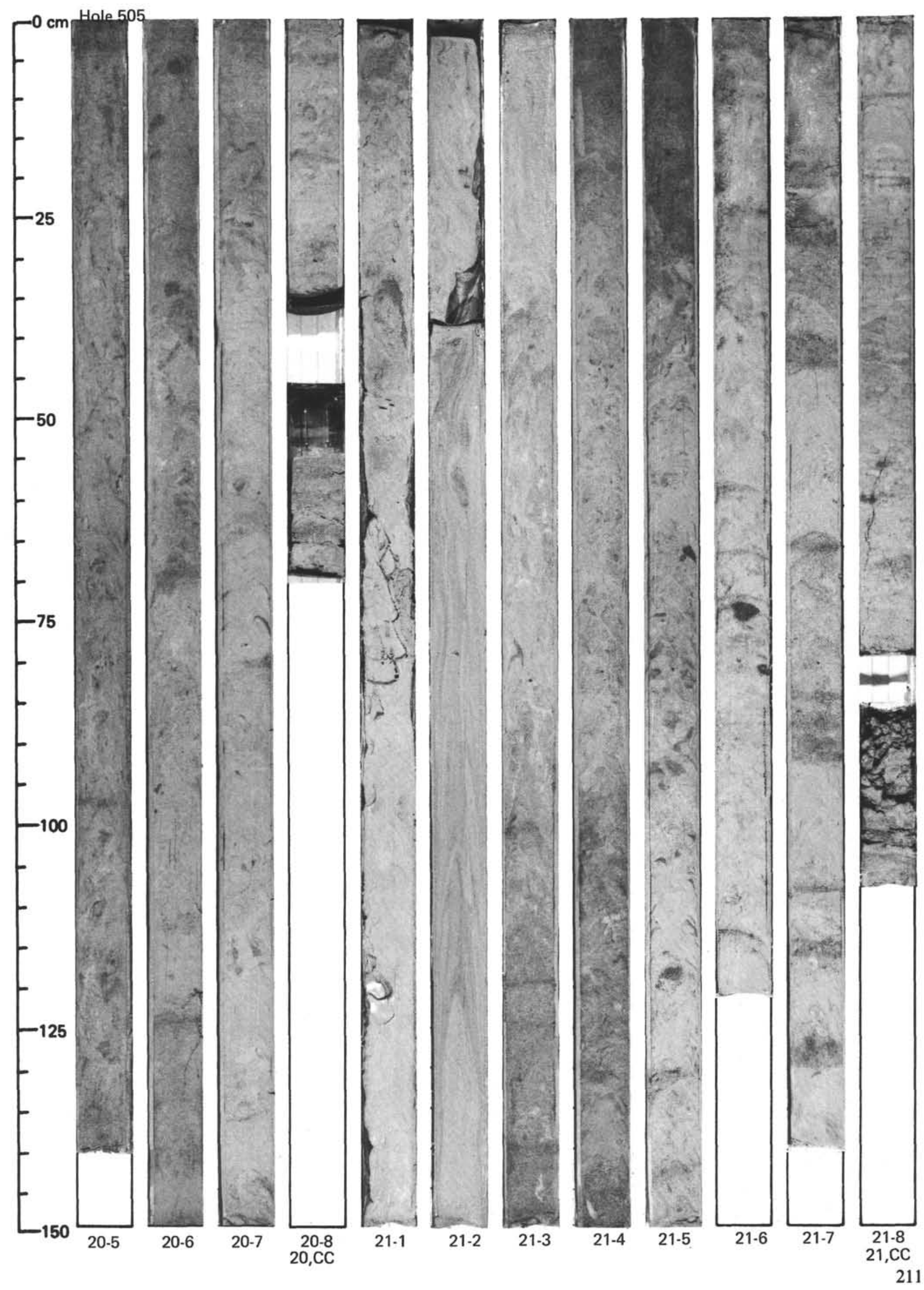




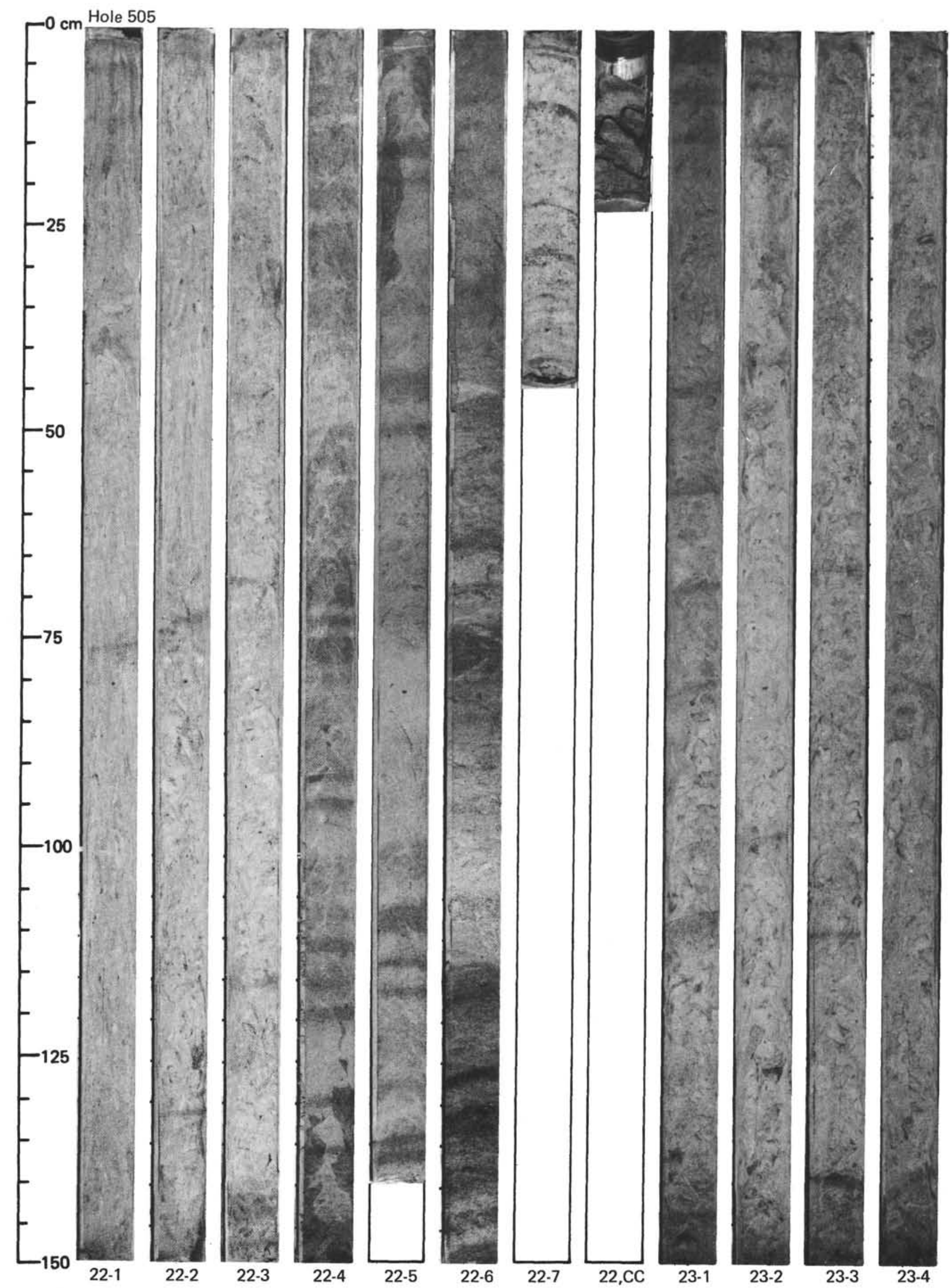




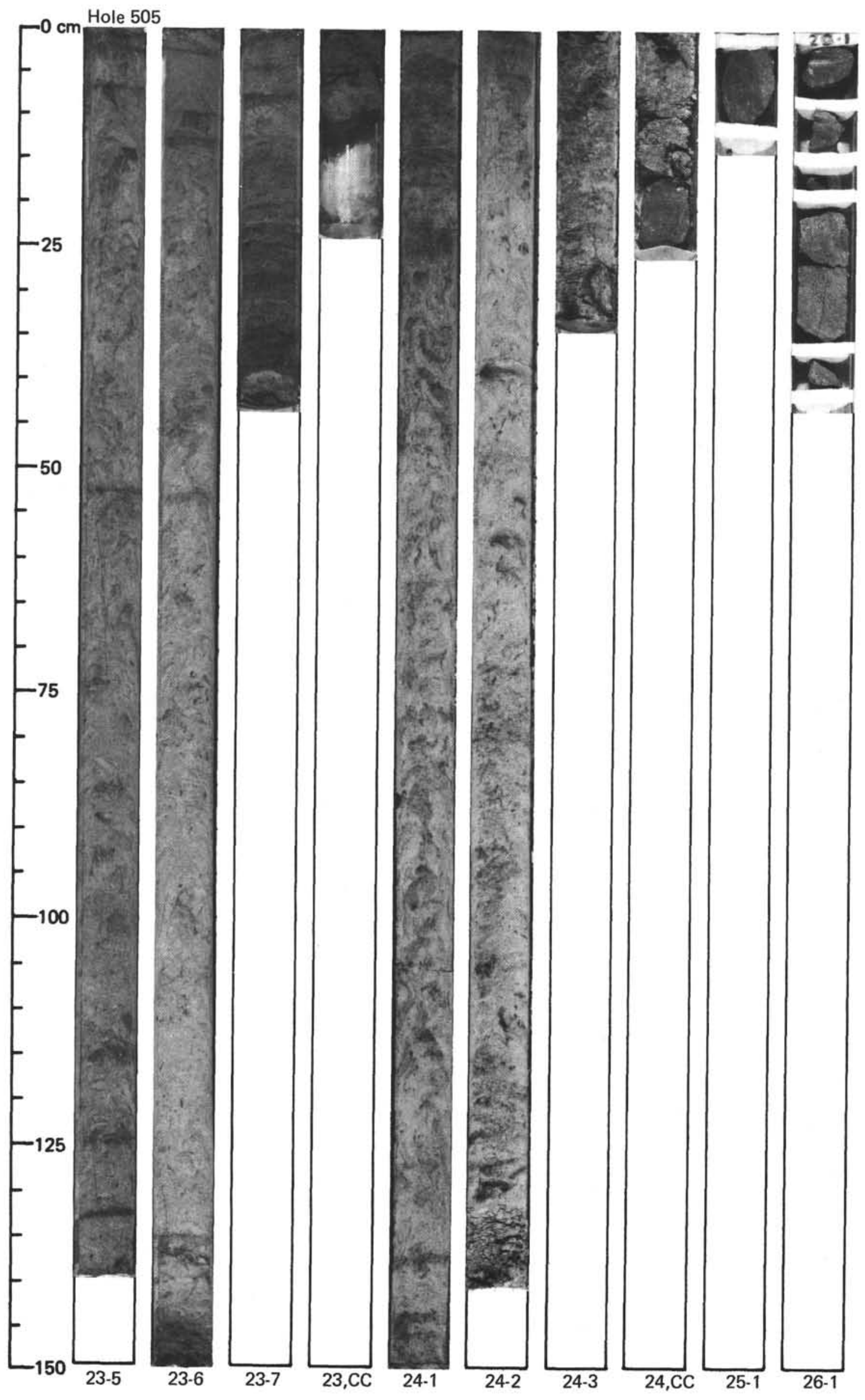




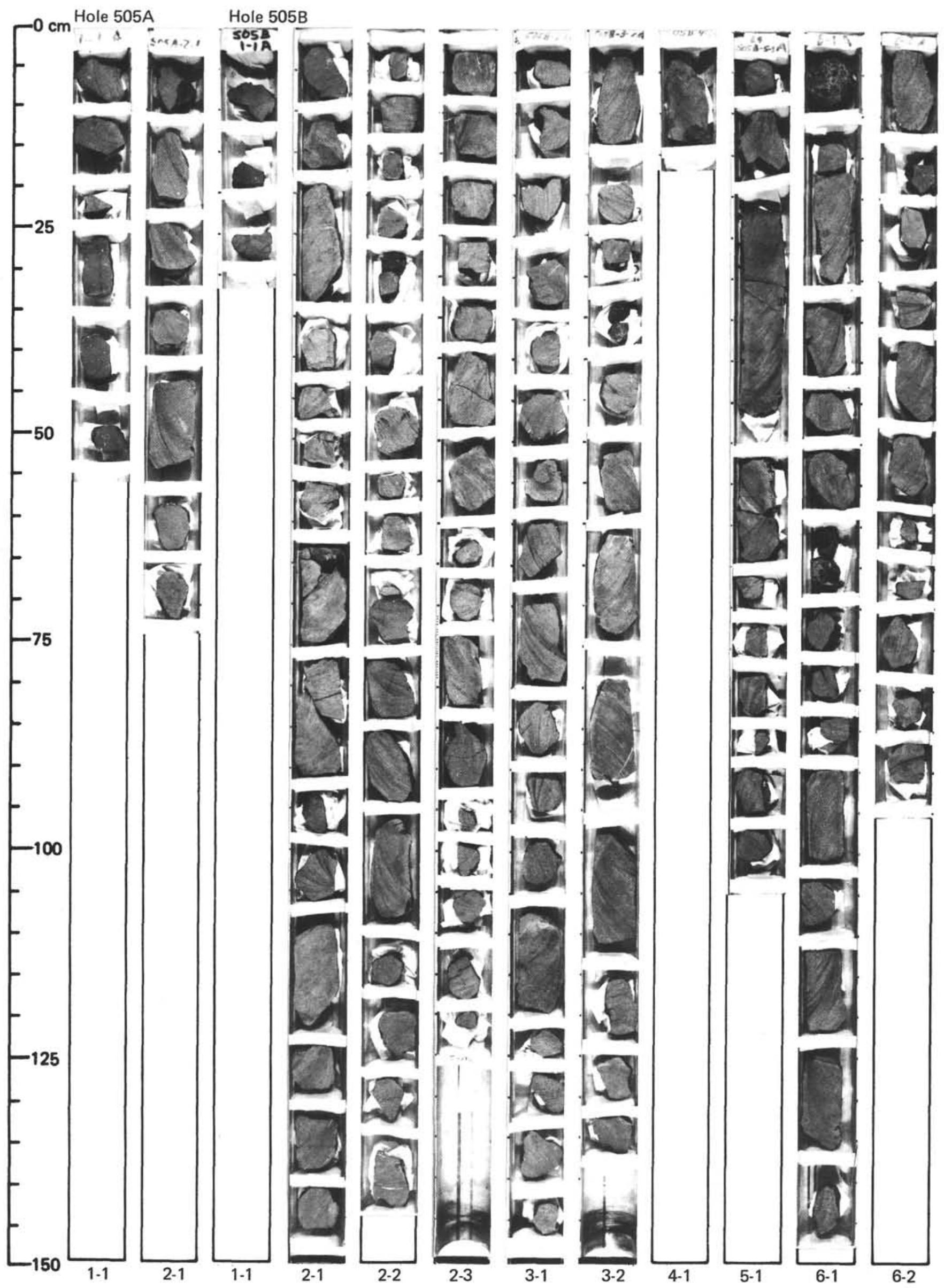

